\title{
Deciphering The Molecular Pathogenesis Behind Neurological Manifestations of SARS-CoV-2 And Drug Repurposing, A Systems Biology Approach
}

maryam mozafar

Tehran University of Medical Sciences School of Pharmacy

\section{Seyed Amir Mirmotalebisohi}

Shahid Beheshti University of Medical Sciences School of Medicine

\section{Marzieh Sameni}

Shahid Beheshti University of Medical Sciences School of Medicine

\section{Zeinab Dehghan}

Shahid Beheshti University of Medical Sciences School of Medicine

\section{Yalda Khazaei-Poul}

Shahid Beheshti University of Medical Sciences School of Medicine

\section{Zargham Sepehrizadeh}

Tehran University of Medical Sciences School of Pharmacy

\section{Mohammad Ali Faramarzi}

Tehran University of Medical Sciences School of Pharmacy

\section{Ahmad Reza Shahverdi}

Tehran University of Medical Sciences School of Pharmacy

hakimeh zali ( $\sim$ hakimehzali@gmail.com )

Shahid Beheshti University of Medical Sciences: Shaheed Beheshti University of Medical Sciences https://orcid.org/0000-0003-2770-5759

\section{Research Article}

Keywords: SARS-CoV-2, HCoV-OC43, gene regulatory network, protein-protein interaction network, neurological manifestations

Posted Date: August 31st, 2021

DOl: https://doi.org/10.21203/rs.3.rs-351801/v2

License: (c) (i) This work is licensed under a Creative Commons Attribution 4.0 International License. Read Full License 


\section{Abstract}

Introduction: As the COVID-19 pandemic spreads worldwide, reports about the neurological complications of SARS-CoV-2 are excessively increasing. However, there is still insufficient high-throughput data on neuronal cells infected with SARS-CoV-2 to help predict its neural pathogenesis. HCoV-OC43 is another member of the beta coronavirus family that has confirmed neuro-invasive effects and has available neural omics data. This study predicts the critical genes, biological processes, and pathways mediating in SARS-CoV-2 neurological manifestations using a systems biology approach.

Method: We retrieved raw data related to SARS-CoV-2 and HCoV-OC43 infections from gene expression omnibus datasets (GSE147507 and GSE13879 respectively). We constructed gene regulatory networks for both infections, detected significant regulatory motifs by FANMOD software, and created their subnetworks. We also constructed PPI networks and identified the MCODE clusters. In the intersection of merged subnetworks of two viruses, the most critical genes were verified in GRN \& PPI networks. We drug-repurposed for the selected target genes and performed the functional enrichment analysis using DAVID and String databases.

Results: Some of the top KEGG pathway results included NF-kappa B, Toll-like receptor, NOD-like receptor, MAPK, and Neurotrophin signaling pathways. The most essential identified genes included IL6, TNF, HOXA5, POU2F2, ITGB3, STAT1, YY1, E2F6, ESR1, FOX03, FOX01, MEF2A, ATF3, ATF4, DDIT3, TCF4, BCL2L2, and BMP4. These genes were also involved in mechanisms of other viral infections of the nervous system. This study repurposes nine medicines with effects on COVID-19 neurological complications. Some of the repurposed drugs were previously registered in clinical trials for COVID-19 treatment.

Conclusion: We recommended some identified crucial genes and medications to investigate further their potential role in treating COVID-19 neurological complications.

\section{Introduction}

Human coronavirus OC43 (HCoV-OC43) is a member of the Coronaviridae family, Nidovirales order, and Coronavirus genus (Kasmi, Khataby et al. 2020). CoVs are enveloped, positive-sense, single-stranded RNA viruses with the largest genome among RNA viruses ( $32 \mathrm{~kb}$ ) (Perlman and Netland 2009). Various viruses belong to the beta-coronavirus genus, including Human coronavirus OC43, human coronavirus HKU1, Middle East Respiratory Syndrome (MERS), and severe acute respiratory syndrome (SARS).

HCoV-OC43 generally causes the common cold, mild upper and lower respiratory tract infections, although it also can show neuroinvasive and neurotropism properties (Beidas and Chehadeh 2018). In vivo studies in mice have demonstrated that HCoV-OC43 can infect neurons and cause encephalitis (Pierre J. Talbot 2011). HCoV-OC43 has been reported in the cerebrospinal fluid of patients with multiple sclerosis. It has also been reported in acute disseminated Encephalomyelitis cases (Arbour, Day et al. 2000, Yeh, Collins et al. 2004). Cases of fatal encephalitis associated with HCoV-OC43 infections are reported even in children (Morfopoulou, Brown et al. 2016). Until recently, our knowledge about the process and dynamics of HCoV-OC43 infection in the CNS is limited, and no effective drug is available to treat the disease (Zumla, Chan et al. 2016, Niu, Shen et al. 2020).

In December 2019, a new coronavirus (SARS-CoV-2) was found in Wuhan, China, which led to a deadly infectious disease called COVID-19. Near one hundred and ninety million cases and over four million deaths have been 
confirmed for the SARS-CoV-2 pandemic worldwide Until 2021 July. SARS-CoV-2 primarily targets the human respiratory system, and its common symptoms include fever, cough, fatigue, headache, hemoptysis, and dyspnea. In severe COVID-19 cases, patients may develop pneumonia, acute respiratory distress syndrome (ARDS), acute cardiac injury, and multi-organ failure (Rothan and Byrareddy 2020).

Similar to HCoV-OC43, the SARS-CoV-2 has also shown neurotropic and neuroinvasive properties. Some new hypothesis has been proposed about the possible routes of SARS-CoV-2 neuroinvasion, including neuronal retrograde, hematogenous, and glymphatic routs (Desforges, Le Coupanec et al. 2019, Battagello, Dragunas et al. 2020). Several neurological manifestations are reported for SARS-CoV-2 infection so far, including headache, dizziness, confusion, ataxia, seizures, acute ischemic stroke, and acute cerebrovascular problems (cerebral venous sinus thrombosis and cerebral hemorrhage) (Chen, Zhou et al. 2020, Huang, Wang et al. 2020, Li, Li et al. 2020, Mao, Jin et al. 2020, Wang, Hu et al. 2020, Yang, Yu et al. 2020). Besides, it seems that choosing suitable drugs for the neural conditions of COVID-19 still requires a more in-depth insight from its molecular pathogenesis. Drug repurposing is an effective drug discovery strategy, which significantly shortens the time and reduces the cost, compared to de novo drug discovery and randomized clinical trials (Zhou, Hou et al. 2020). However, it needs further experimental and population-based validations (Cheng, Desai et al. 2018).

This study first investigated the essential biological processes, biochemical pathways, and crucial genes mediating in the molecular pathogenesis of SARS-CoV-2 infections. We used bioinformatics analysis of gene regulatory elements, including transcription factors and microRNAs, the most essential and well-characterized gene regulators. We also analyzed the host response protein-protein interaction networks (PPINs) to predict the underlying molecular mechanisms associated with HCoV-OC43 and SARS-CoV-2 infections, particularly their neurological manifestations (Yang, Fu et al. 2019, Blanco-Melo, Nilsson-Payant et al. 2020). Besides, we aimed to identify the critical genes responsible for neuronal complications in these patients. However, high-output data for analyzing the HCoV-OC43 infection impacts on neural cells were accessible in array databases; still not sufficient high-output data was available for neuronal cells infected with SARS-CoV-2. Considering the partial phylogenic proximity between the two viruses (both are beta coronavirus) and regarding their similar neuro-invasive effects, we investigated their possible shared molecular mechanisms to predict the molecular mechanisms of the new SARS-CoV-2 responsible for COVID-19 neural manifestations. We compared the host response's gene regulatory networks to the two infections to predict crucial genes accountable for their neural manifestation. The crucial shared genes were then selected as target genes to repurpose new drug candidates, and the new repurposed drug candidates were then validated using the experimental literature.

\section{Material And Methods}

\section{Gene expression analysis related to HCoV-OC43 \& SARS-CoV-2 infections}

The microarray datasets of neural cells infected by HCoV-OC43 were searched and retrieved from the European Array-Express database and the gene expression omnibus (GEO) database (Barrett, Wilhite et al. 2013). Using the GSE13879 dataset (https://www.ncbi.nlm.nih.gov/geo/query/acc.cgi?acc=GSE13879), Dominique J. Favreau et al. (Favreau DJ et al., 2009) had studied the association of HCoV-OC43 with some human neurological diseases. Transcriptional profiling of $\mathrm{N}$-Tera2 differentiated mock-infected human neural cell vs. N-Tera2 differentiated human neural cell infected by HCoV-OC43 at 24, 48, and 72 hours post-infection had been performed using Agilent-012097 Human 1A Microarray (Favreau, Desforges et al. 2009). We used the processed data registered in 
the ArrayExpress databank (https://www.ebi.ac.uk/arrayexpress/experiments/E-GEOD-13879/?query=GSE13879) for the gene dataset (ID: E-GEDD-13879= GSE13879). We then filtered the DEGs based on $\log _{2}$ FC $>0.5$ or $<-0.5$ fold and false discovery rate $p$-value $<0.05$. We first extracted the DEGs related to $24 \mathrm{~h}$ post-infection and then the shared DEGs between $48 \& 72 \mathrm{~h}$ post-infection.

We obtained the SARS-CoV-2 related data from the GSE147507 dataset (https://www.ncbi.nlm.nih.gov/geo/query/acc.cgi?acc=GSE147507) (Blanco-Melo, Nilsson-Payant et al. 2020). Daniel Blanco-Melo et al. investigated the impact of the SARS-CoV-2 on the lung epithelial cell lines (NHBE \& A549) as an in vitro study model. The study has investigated the effect of the SARS-CoV-2 on the lung epithelial cell lines only after 24 hours post-infection. After 24 hours of infection by SARS-CoV-2, the total RNA of the infected and mock cells were extracted and sequenced using an Illumina NextSeq 500 platform. We selected the differentially expressed genes (DEG) of the two cell lines based on $\log _{2} \mathrm{FC}>0.5$ or $<-0.5$ fold and false discovery rate $p$-value $<0.05$.

\section{Protein-protein interaction (PPI) network construction and module detection:}

Up-regulated and down-regulated genes were fed into the STRING database and HIPPIE (Human Integrated Protein-Protein Interaction rEference) (http://cbdm-01.zdv.uni-mainz.de/) separately to retrieve the protein interaction maps. We selected the protein-protein interactions with a confidence score threshold of 0.7 for each gene set. We then imported the interaction tables to Cytoscape software (version 3.7.1) (https://cytoscape.org/) to visualize them and perform topological network analysis (Shannon, Markiel et al. 2003). To map the third PPI network for each gene set, we also used the Bisogenet app to retrieve the HPRD database's interactions. We merged the three PPI networks in Cytoscape and analyzed it, and nominated the top $10 \%$ of the nodes having the highest degree and betweenness centrality as the hub and bottleneck nodes, respectively. Hub genes are defined as highly connected nodes in the PPI network, and networks are usually sensitive to delete the hub genes. Both hub and bottleneck nodes are generally necessary for fundamental cellular processes. (Liu, Yi et al. 2019).

We used the Molecular Complex Detection (MCODE) app to screen the clusters and finding their seed genes. The clusters are highly interconnected regions in a PPI network, and seed genes have the highest degree value in a cluster (Bader and Hogue 2003). The clusters with an MCODE-score bigger than five were then merged to perform functional enrichment analysis.

\section{Gene regulatory networks (GRNs)}

\section{Identification of transcription factors regulating DEGs}

We obtained manually curated TF-target gene interactions from TRANSFAC database (http://genexplain.com/transfac/), which is the gold standard in transcriptional regulation (Wingender 2008), and the TRRUST v2 database, which contains 8444 TF-target regulatory relationships for 800 human TFs (www.grnpedia.org/trrust/)

\section{Identification of microRNAs suppressing DEGs}

We extracted experimentally validated miRNA-target gene interactions from miRecords (http://c1.accurascience.com/miRecords/) and miRTarBase release 8.0 (http://miRTarBase.mbc.nctu.edu.tw/). The miRTarBase was developed to present comprehensive information on experimentally validated miRNA-target 
gene interactions. In this version, the database has collected more than 13,404 validated interactions from 11,021 articles manually curated (Huang, Lin et al. 2020).

\section{Identification of TFs regulating miRs}

We collected literature-curated TF-miRNA regulation from TransmiR v2.0. It contains the TF-miRNA interaction data of 623 TFs and 785 miRNAs for 19 organisms from 1,349 publications. (http://www.cuilab.cn/transmir).

\section{Identification of miRs suppressing TFs}

MicroRNAs post-transcriptionally suppress transcription factors. We considered TFs as target genes and retrieved experimentally validated miR-TF interactions from miRTarBase release 8.0.

\section{GRN construction and motif detection}

We integrated the four types of regulations (TF-gene, miR-gene, TF-miR, and miR-TF) to construct the transcription factor-microRNA-gene regulatory network visualized by Cytoscape software (version 3.7.1). We then merged and exported them to FANMOD software to identify the network's significant 3-node regulatory motifs. FANMOD is a tool for network motif detection that uses a novel algorithm called RAND-ESU (Wernicke and Rasche 2006). We evaluated each of the possible 3-node motif types for their significance using random network generation and built the random networks 1000 times to compare them with the original input network. The 3node motif types having Z-score $>2.0$ and p-value $<0.05$ were considered significant. (The other FANMOD parameters were the same as our previous work with $\mathrm{DOI}: 10.1080 / 17435390.2018 .1513090)$. We then created the motif-related specific subnetworks for each of the significantly scored motifs separately. The motifs with the same FANMOD ID were merged and considered as a unique motif subnetwork.

\section{Functional enrichment analysis}

We performed functional enrichment analysis for Gene Ontology (GO,www.geneontology.org) and Kyoto Encyclopedia of Genes and Genomes (KEGG, https://www.genome.jp/kegg/) on the nodes of the merged PPI clusters and genes of the merged GRN motifs separately using the STRING (string-db.org) and DAVID databases (https://david.ncifcrf.gov) (Huang da, Sherman et al. 2009) (The Gene Ontology Consortium 2019). Biological processes and biochemical pathways with p-value $<0.05$ were considered statistically significant. We selected biological processes and KEGG pathways, which were shared between the enrichment results of both databases.

\section{Identification of critical genes and drug repurposing}

HCoV-OC43 showed neuroinvasive effects in mice and humans; besides, neurological manifestations in patients with SARS-CoV-2 are recently reported (Asadi-Pooya and Simani 2020). Therefore, we used GSE13879, in which the human neuronal cell line was infected with HCoV-OC43 and compared its gene regulatory network with the SARS-CoV-2 network to predict genes responsible for the central nervous system (CNS) involvement in SARS-CoV2 patients. Therefore, the shared genes between the intersections of the motif-related subnetworks of HCoV-OC43 \& SARS-CoV-2 were selected as target genes to repurpose new drug candidates. The genes that played the role of the hubs/bottlenecks of the GRN/PPINs and the genes participating in PPI MCODE clusters were considered the most critical target genes for drug repurposing. We enriched these target genes using the STRING and DAVID databases and reported biological processes and KEGG pathways with $p$-value $<0.05$ enriched in both databases. We retrieved the drug-gene interactions among the medications from three drug databases, including Drug Gene 
Interaction Database (DGIdb) version 3.0.2 (http://dgidb.org/), PharmGKB (https://www.pharmgkb.org/) and DrugBank database version 5.1.6 (https://www.drugbank.ca/) (Wishart, Feunang et al. 2018). We then constructed and visualized the interaction network between the selected genes (available in GRN and PPI networks) and their related drugs using the Cytoscape software. (The medications targeting all the shared target genes were also identified and represented in Supplementary table S14 \& Supplementary table S15) We validated our repurposed drug candidates for possible treatment of neural manifestations of COVID-19 by comparing them with the medications registered in clinical trial platforms for COVID-19 treatment, extracted from the DrugBank database (Wishart, Feunang et al. 2018). The repurposed drugs were also discussed and verified by other experimental reports available in the literature review. The study design and the scheme of the workflow are summarized in fig. 1.

\section{Results}

\section{Gene expression changes related to HCoV-0C43 \& SARS-CoV-2}

In this study, we first investigated how DEGs and their related TF/miRs are involved in biological processes and pathways related to the host response to HCoV-OC43 \& SARS-CoV-2 infections using gene regulatory network and protein-protein interaction network. We extracted the DEGs based on p-value $<0.05$ and $\log _{2}$ fold change $(F C)<-0.5$ or $>0.5$. The DEGs identified for the only microarray dataset available for HCoV-OC43 and RNA sequencing results of two lung epithelial cell lines (NHBE \& A549) infected with SARS-CoV-2 are available in table 1 and supplementary table S1. We first elicited the DEGs related to HCoV-OC43 $24 \mathrm{~h}$ post-infection, and the shared DEGs between $48 \& 72 \mathrm{~h}$. The DEGs related to SARS-CoV-2 were identified for the two cell lines separately and merged to produce the SARS-CoV-2 up and down-regulated gene sets separately for further analysis.

\section{Protein-protein interaction network (PPIN) construction:}

We retrieved the protein-protein interaction maps among the DEGs using the HPRD (by BIOSOGENET app), STRING, and HIPPIE databases. We then merged them to create a PPIN for up and down-regulated genes of each infection, separately. The PPI networks were visualized and topologically analyzed using the Cytoscape software. The number of nodes and edges of each network are represented in table 2 , and the topological network analysis results are available in supplementary table S2. We selected the top $10 \%$ of the PPI network nodes having the highest degree and betweenness centrality as the hub and bottleneck nodes, respectively (available in supplementary table S3).

We investigated the shared DEGs between the HCoV-OC43 (up and down-regulated) networks related to $24 \mathrm{~h}$ postinfection with the SARS-CoV-2 PPI networks. The few numbers of DEGs shared between the two infections are represented in supplementary fig.S1 and supplementary fig.S2 IThe number of the shared genes was not sufficient (six down-regulated and 20 up-regulated shared genes) to construct an intersectional network for further analysis. The shared DEGs between the PPI networks related to HCoV-OC43 48\&72h post-infection and SARSCoV-2 were then investigated and used for further analysis.

\section{MCODE cluster detection and functional enrichment analysis}

The identified clusters of each PPI network and their seed genes using the MCODE plugin are represented in fig. 2 The number of PPI clusters for HCoV-OC43 up and down-regulated genes were eighteen and twenty-six 
subnetworks, respectively. Based on the MCODE-score of more than five, we selected eight clusters of up-regulated and seven clusters of down-regulated genes.

We performed the Gene Ontology and Biochemical KEGG pathway enrichment analysis on the selected PPI clusters' union, using the STRING and DAVID database (based on p-value<0.05). We have described the results that were shared between the two databases in supplementary table S4 and supplementary table S5. The Seed genes of the eight up-regulated clusters were RPLP2, NDUFA3, LSM8, ACKR3, FGA, CBX3, HOXC9, and SYT1. Seed genes of the seven down-regulated clusters included UFL1, APLN, TRA2B, DHX58, COG2, IARS, and HTR4.

The SARS-CoV-2 PPI up and down-regulated networks had nineteen and nine clusters, respectively. We selected the nine up-regulated clusters based on MCODE-score $>5$ and the nine down-regulated clusters based on MCODEscore 3 (no down-regulated cluster score was higher than five). We performed gene ontology and KEGG pathway enrichment analysis on the clusters' merged union, using the STRING database and the DAVID database (based on p-value<0.05). We described the shared biological processes and KEGG pathways in supplementary table S6 and supplementary table S7. The Seed genes of the top nine up-regulated clusters included HLA-F, B2M, UBE2W, IFI44, FGA, TGM1, DDX28, IL1A, and HAUS3. The down-regulated clusters' Seed genes were RAB26, PDE5A, COL20A1, FBXW9, CEP44, TSC22D3, METTL7A, PPARGC1A, and CENPA.

\section{Gene Regulatory Network construction and motif detection}

We extracted four types of regulatory relationships (TF-gene, miR-gene, TF-miR, and miR-TF) for each gene set. The results are available in table 3 and supplementary table S8. We then imported the four regulatory relationships to Cytoscape software (version 3.7.1) and constructed the GRN for each gene set separately. We selected the top $10 \%$ of the GRN nodes having the highest degree and betweenness centrality as the hub and bottleneck nodes, respectively (available in supplementary table S9).

The four types of regulations were then fed into the FANMOD software as an incorporated list for each gene set. The significant 3-node motifs of the GRNS were identified and represented in supplementary fig.S3supplementary fig.S6 (p-value $<0.05, \mathrm{~K}$-score $>2$ ). We selected the motifs with at least two different color edges (represented in fig.3 and fig.4). The selected motif-related subnetworks were created and visualized using the Cytoscape software (version 3.7.1). We merged the motif-related subnetworks with the same FANMOD ID and reported the subnetworks' intersection in fig.5. Our motif detection results showed that all the four gene sets (up and down-regulated genes of HCoV-OC43, and SARS-CoV-2) had the same type of significant motifs with FANMOD IDs 78, 14, and 164.

Biological process and Biochemical pathway enrichment analysis:

We performed enrichment analysis on the DEGs and also on the TFs included in the related DEGs of the merged union of each gene set's motif-related subnetworks, using the STRING and DAVID databases ( $p$-value<0.05). The biological processes and KEGG pathways enriched in both databases are available in supplementary table S10supplementary table S13.

The sub-networks' total union related to the HCoV-OC43 up and down-regulated subnetworks had 325 and 560 genes/TFs. The union of SARS-CoV-2 up and down-regulated genes had 23 and 5 genes/TFs, respectively.

The shared functional enrichment results between the PPINs \& GRNs 
We performed gene ontology and KEGG pathway enrichment analysis on the nodes of merged MCODE clusters of each PPIN and merged motif-related subnetworks of each GRN separately. The shared biological processes and KEGG pathways between enrichment results of PPIN \& GRN of each gene set are available in tables 4 and 5 .

Some of the top biological processes for HCoV-OC43 DEGs included translation, mRNA metabolic process, protein localization, protein modification, and response to virus and stress. Besides, the top ten biological process terms of SARS-CoV-2 up-regulated genes were mostly about immune response, cytokine-mediated, and interferon signaling pathways. Some of the top KEGG pathways of HCoV-OC43 DEGs included Parkinson's disease, Alzheimer's disease, Huntington's disease, NOD-like receptor signaling pathway, Measles, TNF, and NF-kappa B signaling pathway. Some of the top KEGG pathways of SARS-CoV-2 up-regulated genes were Influenza A, Herpes simplex infection, NOD-like receptor signaling pathway, Rheumatoid arthritis, Measles, TNF signaling pathway, Hepatitis C, and Cytokine-cytokine receptor interaction. The number of shared down-regulated DEGs between PPI and GRNs was insufficient to perform the enrichment analysis for SARS-CoV-2 down-regulated genes (supplementary table S7 and supplementary table S13).

\section{Construction of target gene-drug interaction network and drug repurposing}

To predict the genes possibly mediating in neural manifestations of SARS-CoV-2, we identified the intersection between the unions of the motif-related subnetworks of HCoV-OC43 and SARS-CoV-2 GRNs (up and downregulated DEGs, separately). These intersections contained the shared TFs, miRs, and target genes. The number of shared genes between the up-regulated GRN networks was 31, and the number was 35 for the downregulated GRN networks, depicted in fig. 6 and fig.7.

We also enriched the target genes using the STRING and DAVID databases and described the shared biological processes and KEGG pathway results $(p-v a l u e<0.05)$ between the databases in supplementary table S14 and supplementary table S15. The top related KEGG pathways were NF-kappa B, Toll-like receptor, NODlike receptor, Influenza A, Herpes simplex infection, Measles, HTLV-I infection, Hepatitis B, MAPK, and Neurotrophin signaling pathways.

We searched for the medications interacting with the 31 up-regulated and 35 down-regulated target genes in Drug Gene Interaction Database (DGIdb), PharmGKB, and DrugBank databases. In DrugBank, we retrieved interactions of the target genes with previously FDA-approved and pharmacologically active drugs. For the upregulated shared target genes, we found 20 interactions in DrugBank, 184 interactions in DGIdb, and 68 interactions in PharmGKB and the overall number of the repurposed drug/compounds were 251

(supplementary table S16). The numbers were 37, 150, and 42 interactions for the down-regulated shared target genes, respectively, and the overall number was 182 (supplementary table S17).

Among the shared target genes, the GRN and PPIN hubs/bottlenecks and MCODE clusters' nodes were the essential target genes (tables 6 and 7). Eleven of the selected essential target genes were among the HCoV-OC43 DEGs of the 24h post-infection, including TNF, HOXA5, E2F6, ESR1, BCL2L2, DDIT3, PRDM1, RBMX, FOSL1, CRTC3, and KLF13.

From the 31 shared up-regulated target genes, six genes (HOXA5, POU2F2, TNF, ITGB3, STAT1, and IL6) were among the critical genes of both GRN and PPI networks. Therefore, they were nominated as the most crucial target genes. Among the thirty-five shared down-regulated target genes, twelve genes were shared between GRN 
and PPI networks' essential genes. Therefore, they were considered the most crucial target genes, including YY1, E2F6, ESR1, FOX03, MEF2A, TCF4, FOX01, ATF3, BCL2L2, ATF4, DDIT3, and BMP4.

We extracted the drug-gene interactions for the six and twelve critical up and down-regulated target genes, respectively. Among the six up-regulated genes, four of them had drug interactions, and we visualized their 144 drug-gene interactions (129 unique drugs) using Cytoscape (fig.8). Among the twelve down-regulated genes, six had drug interactions. The number of drug interactions visualized for the six down-regulated genes was also 136. (133 unique drugs) (fig.8).

We then investigated our candidate drugs among the 563 medications currently available in clinical trials for their possible effect against SARS-CoV-2, extracted from the DrugBank database (https://go.drugbank.com/covid-19 ). The number of medications repurposed for the up-regulated critical target genes currently registered for SARSCoV-2 treatment clinical trials was 35 , and the number was 20 for the down-regulated (table 8 ).

\section{Discussion}

This study analyzed and compared the DEGs related to lung epithelial cell lines (NHBE and A549) treated with SARS-CoV-2 and N-Tera2 differentiated human neuronal cells treated with HCoV-OC43 to investigate the possible molecular mechanisms behind the neurological manifestations of SARS-CoV-2 infection. We constructed TF-miRgene regulatory and protein-protein interaction networks to identify the critical nodes (hubs, bottlenecks, motif members, and MCODE cluster members), biological processes, and pathways mediating in the two infections' pathogenesis. The shared critical genes between the HCoV-OC43 effect on neural cells and SARS-CoV-2 could shed light on the molecular mechanisms of brain conditions in COVID-19 patients (fig.9). Herein, we discuss and validate some of the predicted genes and pathways probably mediating in neural manifestations of COVID-19 using other experimental literature.

This study investigated the genes mediating in the central nerve system (CNS) involvement of SARS-CoV-2 using the shared genes between both OC43 and SARS-CoV-2 GRN and PPI networks. The most critical genes included six up-regulated shared genes (IL6, TNF, HOXA5, POU2F2, ITGB3, and STAT1) and 12 down-regulated shared genes (YY1, E2F6, ESR1, FOX03, FOX01, MEF2A, ATF3, ATF4, DDIT3, TCF4, BCL2L2, and BMP4). Several other studies have previously reported the mentioned critical genes to be involved in neural proliferation and differentiation (neurodevelopment), neurotransmission, synaptic plasticity, and myelination (Each molecule is separately described and referred to in table 9) (Yang, Lindholm et al. 2002, Nakanishi, Niidome et al. 2007, Ragel, Couldwell et al. 2007, He and Casaccia-Bonnefil 2008, Imamura, Satoh et al. 2008, Lange, Chavez et al. 2008, Islam, Gong et al. 2009, Renault, Rafalski et al. 2009, Leung and Cahill 2010, Oh, McCloskey et al. 2010, Zolova and Wight 2011, Hunt, Raivich et al. 2012, Pozo, Cingolani et al. 2012, Cosker, Pazyra-Murphy et al. 2013, Wang, Choi et al. 2013, Ma, Tang et al. 2014, Mazalouskas, Jessen et al. 2015, Varney, Polston et al. 2015, Doan, Kinyua et al. 2016, Kennedy, Rahn et al. 2016, Chen, Gao et al. 2017, Lizen, Moens et al. 2017, Higashi, Tanaka et al. 2018, Li, Jin et al. 2018, Liu, Amar et al. 2018, Zhu, Carmichael et al. 2018, Liu, Yu et al. 2019, Majidi, Reddy et al. 2019, Masgutova, Harris et al. 2019, Wu and Donohoe 2019, Hartman and Czyz 2020, Pennycook, Vesela et al. 2020). Below, we have hypothesized how some of these in-silico identified critical genes can play roles in neural manifestations of COVID-19 pathogenesis. 
The SARS-CoV-2 RNA acts as a viral pathogen-associated molecular pattern (PAMPs) that can be identified by pattern-recognition receptors (PRRs) like toll-like receptors (TLRs) and NOD (nucleotide-binding oligomerization domain)-like receptors (NLRs) (Kopitar-Jerala 2015). The surface receptors were among the top enrichment results of KEGG pathways of the shared DEGs between the two infections and are the first molecules activated in the innate immune system against the CNS pathogens. An inflammatory cascade initiates after triggering TLRs 3 , 7,8 , and 9 by activating the NF-kB signaling pathway and IFN a/ $\beta / Y$ gene expression (Sabroe, Parker et al. 2008, Totura, Whitmore et al. 2015). The NF-kB pathway was also another pathway enriched for the shared DEGs. It regulates gene expression by $\mathrm{kB}$ sites present in promoter and enhancer regions of various essential genes such as chemokines, cytokines, adhesion molecules, and pro-inflammatory transcription factors. Therefore, it regulates neuronal survival and neuronal inflammatory reactions. The NF-KB also induces pro-IL-1ß, pro-IL-18, TNF, and IL6 (Tergaonkar, Correa et al. 2005, Tergaonkar 2006, Wong and Tergaonkar 2009). The TNF and IL-6 were identified as hub/bottlenecks in the GRN/ PPI networks of our in-silico analysis.

SARS-CoV-2 can also be recognized by NLRP3 (a kind of NLRs). NLRP3 forms an inflammasome complex with caspase-1 and cleaves IL-1 $\beta$ and IL-18 to mature forms (Zhao and Zhao 2020). These cytokines (IL-1 $\beta$, IL-18, TNF, and IL-6) induce further NF-KB nuclear translocation, activation of the JAK/STAT pathway, and phosphorylation of p38 MAPK (Battagello, Dragunas et al. 2020). The pathways were also included among our top ten enrichment results of the shared genes. Activation of p38s regulates immune response and inflammatory processes in SARSCoV-2 infection (Feng, Fang et al. 2019, Grimes and Grimes 2020). In CNS, elevated activity of MAPK signaling can modulate neuronal survival and homeostasis (Feng, Fang et al. 2019, Grimes and Grimes 2020). Besides, in the JAK/STAT pathway, cytokines like INF and IL-6 bind to their receptors, induce JAK proteins cross-

phosphorylation and then recruit STAT proteins. The phosphorylated STAT proteins then dimerize and translocate into the nucleus and regulate gene expression as transcription factors and (O'Shea, Schwartz et al. 2015). STAT1 and STAT3 were also identified as two crucial genes in our GRN/PPI networks. STAT1 has an essential role in the IFN signaling type I and type II and the JAK/STAT pathway (Pasieka, Cilloniz et al. 2011, Kulkarni, Scully et al. 2017). The role of STAT-1 has been previously elucidated in the innate immune response to other neurotropic viruses such as the severe acute respiratory syndrome coronavirus (SARS), Herpes simplex virus type 1 (HSV-1), and West Nile virus (WNV) (Pasieka, Cilloniz et al. 2011, Mahlakõiv, Ritz et al. 2012, Winkelmann, Luo et al. 2016).

The neurotrophin signaling pathway was another enriched result between the shared genes of our in-silico study. The pathway makes crosslinks with various intracellular signaling cascades, including NF- kB and MAPK pathways. Neurotrophins, such as nerve growth and brain-derived neurotrophic factors, induce neurons' survival, development, and function (Reichardt 2006).

In the nervous system, IL-6 and TNF-a are typically expressed at relatively low levels. However, their expression is up-regulated under different pathological conditions like inflammation and viral infections (Yang, Lindholm et al. 2002, Oh, McCloskey et al. 2010). SARS-CoV-2 can activate glial cells in the CNS and induce a pro-inflammatory state. IL-6 and TNF-a play essential roles in the Systemic Inflammatory Response Syndrome (SIRS), leading to brain damage (Li, Fu et al. 2004, Liguori, Pierantozzi et al. 2020, Serrano-Castro, Estivill-Torrús et al. 2020, Wan, Yi et al. 2020). The IL-6 level also increases in other viral respiratory infections with neurological complications such as a human respiratory syncytial virus (RSV) and Influenza. It can be considered as an indicator of their neurologic prognosis (Aiba, Mochizuki et al. 2001, Kawashima, Kashiwagi et al. 2012, Morichi, Morishita et al. 2017). 
HOXA5 was identified as another critical gene in our in-silico analysis. It is a member of the HOX family of transcription factors expressed throughout adulthood, especially in glutamatergic and GABAergic neurons. It regulates many genes associated with neuronal survival and synaptic function (Lizen, Moens et al.

2017). HoxA5 is reported to regulate the viral immediate-early (IE) gene expression in herpes simplex virus (HSV). Besides, the IE gene has an essential role in acute viral replication and its latency in neurons (Mitchell, De Santo et al. 1993, Mitchell 1995). HOXA5 expression is also reported to change significantly in some other neurotrophic viral infections like Cytomegalovirus, Coxsackievirus B3 (CVB3), and lymphocytic choriomeningitis virus (LCMV). The viruses can infect neurons and cause meningitis and encephalitis (Ester 2011, Puccini, Ruller et al. 2014).

POU2F2 (Oct-2) was another identified crucial gene. It has an essential role in virus replication and is a member of the POU family. It is predominantly expressed in B cells, activated T cells, and the nervous system (Luchina, Krivega et al. 2003). Some POU family members, such as POU2F1, are reported to be necessary for viral DNA replication and gene expression in other viruses such as herpes simplex virus (HSV) (Ryan and Rosenfeld 1997). It can be hypothesized that SARS-CoV-2 elevates the expression of HOXA5 and POU2F1 to increase its viral proliferation possibly.

The ITGB3 gene, coding for the integrin $\beta 3$ subunit, is expressed and enriched at cortical, hippocampal, and midbrain synapses in the brain (Varney, Polston et al. 2015). The integrin $\beta 3$ mediates in HSV- 1 cell entry by relocating HSV receptor nectin1, and thus HSV to cholesterol-rich microdomains of the membrane where TLR2 presents. Therefore, integrin $\beta 3$ plays a vital role in endocytosis of the virus and initiation of the innate immune response (NF-KB activation and production of IFNa, IFN $\beta$, IL2, and IL10) (Gianni, Leoni et al. 2012, Gianni, Leoni et al. 2013). The ITGB3 was up-regulated in our in-silico results. Therefore, we suggest that SARS-CoV-2 is probably utilizing this upregulation to increase its entry. However, further experimental studies are required to confirm the prediction.

The antiviral response is also activated by Yin Yang 1 (YY1). It is a multi-functional transcription factor that can activate or repress gene expression in various cell types, including neurons (He and Casaccia-Bonnefil 2008, Chen and Chan 2019). Some Viral infections down-regulate the expression of YY1 since it can mediate the antiviral innate immune response and regulate the production of interferon-beta (IFN- $\beta$ ) (Zan, Zhang et al. 2017). YY1-1 can also repress the transcription of many retroviruses such as human immunodeficiency virus type I (HIV1). It also contributes to a neurological disorder caused by the human T lymphotropic virus type 1 (HTLV-1) (Coull, Romerio et al. 2000, Wang and Goff 2020). We also identified the YY1 as a downregulated gene in SARS-CoV-2 and OC-43 infections. Therefore, it can be postulated that the virus is probably benefiting from the YY1-1 downregulation in its neural pathogenesis in COVID-19. E2F6 expression is a known mechanism that slows down or exits the cells from S-phase. Some viral proteins can inactivate E2F6 to extend the S-phase in virus-infected cells, such as human papillomavirus (HPV) E7 proteins, simian virus $40 \mathrm{~T}$ antigen, and adenovirus E1A (McLaughlin-Drubin, Huh et al. 2008). Our results showed that SARS-CoV-2 infection down-regulates the expression of E2F6. The E2F6 downregulation presumably contributes to the replication of the virus.

The Forkhead box 0 transcription factors (FOX01 and 3) were the next identified critical genes. They mediate the regulation of the cell cycle, apoptosis, autophagy, and DNA repair. They also are reported to regulate neural cell survival, neuronal signaling, and stress responses in the nervous system (Santo and Paik 2018, Schäffner, Minakaki et al. 2018). Our results showed that SARS-CoV-2 down-regulated the FOXO proteins similar to other viruses such as the Japanese encephalitis virus (JEV). JEV induces cell apoptosis in neurons by inhibiting the FOXO-signaling pathway. Therefore, it can lead to severe viral encephalitis in humans and other animals (Guo, Yu 
et al. 2018). Furthermore, FOXO proteins have a validated role in the pathogenesis of HIV-I-infection and its associated neurological complications (Cui, Huang et al. 2009).

ESR1 (Estrogen receptor $\mathrm{a}$ ) is present in the hypothalamus and amygdala regions related to human emotion and cognitive functions (Ma, Tang et al. 2014). It is also involved in the pathogenesis of hepatitis viruses (HBV \& HCV) and their complications (Deng, Zhou et al. 2004, Zhai, Zhou et al. 2006, Watashi, Inoue et al. 2007). Neurological complications of these viruses range from peripheral neuropathy to cognitive impairment (Mathew, Faheem et al. 2016). SARS-CoV-2 is also a positive-sense RNA virus similar to HCV. Therefore, we predict that the molecular mechanisms behind the two viruses' similar neurological complications are probably the same, and we recommend the prediction for further experimental investigations.

Myocyte enhancer factor 2 (MEF2, isoform A) is also highly expressed in the brain. MEF2A is a downstream protein of NMDA receptor-mediated excitotoxicity in which excessive stimulation of the NMDA receptor contributes to the death of neurons. It is also reported to mediate in the neuropathogenesis of some other single-strand RNA-viruses such as HIV-1 (Kaul and Lipton 2004, Yndart, Kaushik et al. 2015). The MEF2A was identified as a critical gene and is recommended for further studies in the neuropathogenesis of SARS-CoV-2, similar to HIV-1.

Activating transcription factors (ATFs) are members of the ATF/cAMP response element-binding protein (CREB) family. ATF3 and ATF4 usually are low in neural cells, but their expression increases rapidly in response to pathological stress (Lange, Chavez et al. 2008, Hunt, Raivich et al. 2012). Activation of innate and adaptive immune systems can induce the expression of ATF3. However, ATF3 acts as a negative regulator of the immune response (Hunt, Raivich et al. 2012). Our analysis showed that SARS-CoV-2 down-regulated the ATF3. Therefore, it can be suggested that down-regulation of ATF3 possibly mediates in hyper-activation of the immune system and neural manifestations of some patients with severe COVID-19. ATF4 is a downstream protein of a cellular protective signaling pathway called the Unfolded Protein Response (UPR). UPR and Autophagy pathways are tightly interconnected and are reported to play a vital role in some viral infections such as hepatitis $C$ virus, herpes simplex virus type 1 (HSV-1), Influenza virus, and severe acute respiratory syndrome (SARS) (Tardif, Mori et al. 2004, Versteeg, van de Nes et al. 2007, Burnett, Audas et al. 2012, Sen, Balakrishnan et al. 2014, Sims and Meares 2019). We hypothesize that SARS-CoV-2 probably modulates the UPR/Autophagy signaling pathways to produce large quantities of viral proteins. Besides, ATF4 (CERB-2) interacts with Human T-cell leukemia virus type 1 (HTLV1) tax protein to regulate its transcription. The virus causes a severe neurologic disorder called HTLV-1 associated myelopathy/tropical spastic paraparesis (HAM/TSP) (Ahuja, Kampani et al. 2006, Barbeau and Mesnard 2011).

DDIT3 (DNA damage-inducible transcript 3) was another down-regulated critical gene in our in-silico results. It is a downstream protein of ATF4 in unfolded protein response (UPR), which can activate the autophagy pathway (Bello-Perez, Sola et al. 2020). DDIT3 also downregulates BCL2, which is involved in the apoptosis pathway and autophagy flux (Nabirotchkin 2020). Therefore, SARS-CoV-2, similar to other previously known coronaviruses, dysregulates these three genes (ATF4, DDIT3, BCL2) to possibly exploit the autophagy molecular machinery and replicate more rapidly (Bello-Perez, Sola et al. 2020, Mamoor 2020, Nabirotchkin 2020). DDIT3 is also dysregulated in other viral infections such as the Zika virus (ZIKV), Tick-borne encephalitis virus (TBEV), and West Nile virus (WNV). The three viral infections can progress to the CNS and cause encephalitis or meningitis in severe cases (Selinger, Wilkie et al. 2017, Huang, West et al. 2019, Ojha, Rodriguez et al. 2019, Bonenfant, Meng et al. 2020). 
Bcl2l2 (Bcl-w) is an Anti-apoptotic member of The B-cell lymphoma-2 (BCL-2) family (Hartman and Czyz 2020). Various viruses are reported to interact with the $\mathrm{Bcl}-2$ family to regulate the cellular apoptosis, including Influenza A virus, hepatitis B virus, hepatitis $C$ virus, Epstein-Barr virus, vesicular stomatitis virus, human immunodeficiency virus, and SARS-CoV. (Tan, Tan et al. 2007, Nencioni, De Chiara et al. 2009, Pearce and Lyles 2009, Busca, Saxena et al. 2012, Geng, Huang et al. 2012, Park, Kang et al. 2012, Ghigna, Reineke et al. 2013). Some of the viruses have previously been reported with neural complications. The Influenza A virus and SARS-CoV are reported to suppress BCL-W and Bcl-XL (another anti-apoptotic member of the family) to induce cellular apoptosis and subsequent tissue damage (Tan, Tan et al. 2007, Nencioni, De Chiara et al. 2009, Guan, Shi et al. 2012). Our results showed that SARS-CoV-2 also down-regulates Bcl-w, Similar to SARS-CoV. The Bcl-w probably also mediates in SARS-CoV2 subsequent tissue damage in a similar way.

BMP4 is one of the Bone morphogenetic proteins (BMPs), which are members of the transforming growth factorbeta (TGF-b) superfamily (Higashi, Tanaka et al. 2018). TGF-beta and BMP signaling pathways are activated following some neurotropic viral infections, such as reovirus. The signaling pathways are part of the host immune response and have a neuroprotective effect (Beckham, Tuttle et al. 2009). Besides, the synergistic activation of BMP and alpha-interferon signaling pathways is also reported to reduce the hepatitis $C$ virus [136]. Based on our results, the SARS-CoV-2 down-regulated the BMP4. Therefore, we suggest that the virus probably is benefitted from the BMP4 down-regulation in infected neurons.

In this study, we investigated our 259 repurposed medicines indications and mechanisms using the DrugBank database. Our emphasis was on drugs that affect the nervous system; since SARS-CoV-2 is a neurotropic virus, and the immune system's hyperactivation has a vital role in its complications (table 8). We also reported the drug candidates that were categorized as inflammatory drugs or antiviral drugs. We have reported forty-four drugs with immunomodulatory or immunosuppressive functions that have validated effects in treating inflammatory or autoimmune diseases such as rheumatoid arthritis, psoriatic arthritis, ankylosing spondylitis, Chron's disease, ulcerative colitis, systemic lupus erythematosus, and Behcet's disease (Suzuki Kurokawa and Suzuki 2004, Allison 2005, Potthast, Dressman et al. 2005, Klotz, Teml et al. 2007, Mease 2007, Lucas 2016, Corbett, Chehadah et al. 2017, Laurence L. Brunton 2018, Yang, Wu et al. 2018, Afra, Razmi et al. 2019). Ten antiviral medications (mostly anti-HIV-1 and hepatitis) were also among our repurposed drugs. For example, Hydroxychloroquine and chloroquine were two drugs reported to inhibit the viral entry by changing the endosomal $\mathrm{PH}$ and disrupting glycosylation of ACE2 (Vincent, Bergeron et al. 2005, Plantone and Koudriavtseva 2018, Devaux, Rolain et al. 2020, Wang, Cao et al. 2020).

Our repurposed medications that have validated effects in the nervous system included 1-Risperidone (schizophrenia and bipolar disorders), 2-lbudilast (neuroprotective in multiple sclerosis), 3-Carbamazepine (control seizures, trigeminal neuralgia, and Bipolar disease), 4-Midazolam (hypnotic-sedative, muscle relaxant and anticonvulsant ), 5-pyridoxine (synthesis of the neurotransmitters), 6-Duloxetine (neuropathic pain and Generalized Anxiety disorder), 7-melatonin (sleep-wake cycle disturbances), 8-Rizatriptan (migraine), and 9selective serotonin receptor inhibitors (antidepressant) (Tambasco-Studart, Titiz et al. 2005, Chen and Lin 2012, Tolou-Ghamari, Zare et al. 2013, Kennedy, Lam et al. 2016). We have also discussed Ibudilast's neuroprotective properties, Melatonin, Pyridoxine, and SSRIs, to validate the repurposed drugs.

Ibudilast suppresses the excess production of pro-inflammatory cytokines such as interleukin IL-1 $\beta$, IL-6, and TNF$a$ in the CNS. This anti-inflammatory property can help treat other viral-related neurocognitive disorders, such as HIV-associated neurocognitive disorders (HAND) and other neuro-inflammatory diseases [155-157]. Our SARS- 
CoV-2 treated cells in-silico results also showed the up-regulation of IL-1 $\beta, I L-6$, and TNF-a. Therefore, it can be recommended as a possibly suitable repurposed drug for COVID-19 neural manifestations' investigations (in vitro and in vivo).

Melatonin seems a suitable candidate in treating COVID-19 since it shows excellent anti-oxidative properties by directly scavenging free radicals and stimulating antioxidant enzymes. Furthermore, Melatonin has antiinflammatory effects by reducing pro-inflammatory cytokines and balancing innate immune response's overactivation while promoting adaptive immunity $[158,159]$. The published reports related to Melatonin used in the animals with deadly viral infections such as Venezuelan equine encephalomyelitis virus (VEEV), Semliki Forest virus (SFV), and West Nile virus (WNV) showed that Melatonin is not viricidal. However, somewhat it reduces the severity of viral infections $[158,159]$. Adequate Pyridoxine supplementation can prevent polyneuropathy, which is the most common neurological complication associated with HIV $[160,161]$. Perhaps, Pyridoxine can be helpful in such kinds of pains in COVID-19 patients.

Serotonin shows immunomodulatory properties by downregulating central and peripheral inflammatory responses. So selective serotonin reuptake inhibitors (SSRIs) such as fluoxetine (with a clinical trial ID of NCT04377308) and Fluvoxamine (NCT04342663) could effectively dampen the excessive production of cytokines and prevent neurological complications in various neurocognitive disorders and COVID-19 [162].

We investigated the number of shared medicines between our list and the list of all registered drugs for COVID-19 clinical trials to verify our repurposed medications for their possible use in treating neural manifestations of COVID-19. Fifty-four of our repurposed medications were previously registered for investigations against COVID19 (table 8).

\section{Conclusion}

The current study revealed significant regulatory motifs and clusters of protein-protein interactions that play essential roles in the pathogenesis of HCoV-0C43 \& SARS-CoV-2. With the accessible information on neuronal cells infected with HCoV-OC43, we predicted crucial genes, biological processes, and pathways in SARS-CoV-2 neurological manifestations that were mostly linked to activation of the innate immune system in CNS. This bioinformatics analysis can help shed light on molecular mechanisms and interactions involved in the neurological aspects of COVID-19. This study recommends some identified crucial genes and medications for further investigations in vitro and in vivo.

\section{Declarations}

\section{Acknowledgments}

This study is a part of the Ph.D. thesis of Maryam Mozafar. The study was jointly conducted by Tehran University of Medical Sciences (TUMS) and Shahid Beheshti University of Medical Sciences (SBMU). We thank the Student Research Committee of the Department of Biotechnology in SBMU School of Advanced Technologies in Medicine, SBMU Cellular and Molecular Biology Research Center, and SBMU Proteomics Research Centre for their support in this study.

\section{Funding}


No funding was received for conducting this study.

\section{Conflict of interest}

The authors have no conflicts of interest to declare that are relevant to the content of this article.

\section{Availability of data and material}

All authors confirm that all data and materials as well as software application or custom code support their published claims and comply with field standards.

\section{Code availability}

Not applicable

\section{Authors' contributions}

All authors contributed to the study design. Maryam Mozafar, Seyed Amir Mirmotalebisohi, and Hakimeh Zali performed Material preparation, data collection and analysis. Maryam Mozafar and Seyed Amir Mirmotalebisohi wrote the first draft of the manuscript. All authors supervising on completing this version of the manuscript. All authors read and approved the final manuscript.

\section{Ethics approval}

Not applicable

\section{Consent to participate}

Not applicable

\section{Consent for publication}

Not applicable

\section{References}

1. Afra TP, Razmi TM, Dogra S (2019) Apremilast in Psoriasis and Beyond: Big Hopes on a Small Molecule. Indian Dermatol Online J 10(1):1-12

2. Ahuja J, Kampani K, Datta S, Wigdahl B, Flaig K, Jain P (2006) Use of human antigen presenting cell gene array profiling to examine the effect of human T-cell leukemia virus type 1 Tax on primary human dendritic cells. J Neurovirol 12:47-59

3. Aiba H, Mochizuki M, Kimura M, Hojo H (2001) Predictive value of serum interleukin-6 level in influenza virusassociated encephalopathy. Neurology 57(2):295-299

4. Allison AC (2005) "Mechanisms of action of mycophenolate mofetil. " Lupus 14(Suppl 1):s2-8

5. Arbour N, Day R, Newcombe J, Talbot PJ (2000) Neuroinvasion by Human Respiratory Coronaviruses. J Virol 74(19):8913 
6. Asadi-Pooya A, Simani L (2020) Central nervous system manifestations of COVID-19: A systematic review. J Neurol Sci 413:116832

7. Bader GD, Hogue CW (2003) An automated method for finding molecular complexes in large protein interaction networks. BMC Bioinformatics 4:2

8. Barbeau B, Mesnard JM (2011) "Making sense out of antisense transcription in human T-cell lymphotropic viruses (HTLVs). " Viruses 3(5):456-468

9. Barrett T, Wilhite SE, Ledoux P, Evangelista C, Kim IF, Tomashevsky M, Marshall KA, Phillippy KH, Sherman PM, Holko M, Yefanov A, Lee H, Zhang N, Robertson CL, Serova N, Davis S, Soboleva A (2013) "NCBI GEO: archive for functional genomics data sets-update". Nucleic Acids Res 41(Database issue):D991-D995

10. Battagello DS, Dragunas G, Klein MO, Ayub ALP, Velloso FJ, Correa RG (2020) "Unpuzzling COVID-19: tissuerelated signaling pathways associated with SARS-CoV-2 infection and transmission". Clin Sci (Lond) 134(16):2137-2160

11. Beckham J, Tuttle KD, Tyler K (2009) Reovirus Activates Transforming Growth Factor\#² and Bone Morphogenetic Protein Signaling Pathways in the Central Nervous System That Contribute to Neuronal Survival following Infection. J Virol 83:5035-5045

12. Beidas M, Chehadeh W (2018) "PCR array profiling of antiviral genes in human embryonic kidney cells expressing human coronavirus OC43 structural and accessory proteins". Arch Virol 163(8):2065-2072

13. Bello-Perez M, Sola I, Novoa B, Klionsky DJ, Falco A (2020) "Canonical and Noncanonical Autophagy as Potential Targets for COVID-19." Cells 9(7)

14. Blanco-Melo D, Nilsson-Payant BE, Liu W-C, Møller R, Panis M, Sachs D, Albrecht RA, tenOever BR (2020) "SARS-CoV-2 launches a unique transcriptional signature from in vitro, ex vivo, and in vivo systems." bioRxiv: 2020.2003.2024.004655

15. Bonenfant G, Meng R, Shotwell C, Badu P, Payne AF, Ciota AT, Sammons MA, Berglund JA, Pager CT (2020) "Asian Zika Virus Isolate Significantly Changes the Transcriptional Profile and Alternative RNA Splicing Events in a Neuroblastoma Cell Line." Viruses 12(5)

16. Burnett HF, Audas TE, Liang G, Lu RR (2012) Herpes simplex virus-1 disarms the unfolded protein response in the early stages of infection. Cell Stress Chaperones 17(4):473-483

17. Busca A, Saxena M, Kumar A (2012) "Critical role for antiapoptotic Bcl-xL and Mcl-1 in human macrophage survival and cellular IAP1/2 (cIAP1/2) in resistance to HIV-Vpr-induced apoptosis". J Biol Chem 287(18):15118-15133

18. Chen A, Lin S-K (2012) Carbamazepine treatment of bipolar disorder: A retrospective evaluation of naturalistic long-term outcomes. BMC Psychiatry 12:47

19. Chen N, Zhou M, Dong X, Qu J, Gong F, Han Y, Qiu Y, Wang J, Liu Y, Wei Y, Xia J, Yu T, Zhang X, Zhang L (2020) Epidemiological and clinical characteristics of 99 cases of 2019 novel coronavirus pneumonia in Wuhan, China: a descriptive study. Lancet 395(10223):507-513

20. Chen X, Gao B, Ponnusamy M, Lin Z, Liu J (2017) MEF2 signaling and human diseases. Oncotarget 8(67):112152-112165

21. Chen ZS, Chan HYE (2019) "Transcriptional dysregulation in neurodegenerative diseases: Who tipped the balance of Yin Yang 1 in the brain?". Neural Regen Res 14(7):1148-1151

22. Cheng F, Desai RJ, Handy DE, Wang R, Schneeweiss S, Barabási A-L, Loscalzo J (2018) "Network-based approach to prediction and population-based validation of in silico drug repurposing". Nat Commun 
9(1):2691

23. Corbett M, Chehadah F, Biswas M, Moe-Byrne T, Palmer S, Soares M, Walton M, Harden M, Ho P, Woolacott N, Bojke L (2017) Certolizumab pegol and secukinumab for treating active psoriatic arthritis following inadequate response to disease-modifying antirheumatic drugs: a systematic review and economic evaluation. Health Technol Assess 21(56):1-326

24. Cosker KE, Pazyra-Murphy MF, Fenstermacher SJ, Segal RA (2013) "Target-derived neurotrophins coordinate transcription and transport of bclw to prevent axonal degeneration". J Neurosci 33(12):5195-5207

25. Coull JJ, Romerio F, Sun JM, Volker JL, Galvin KM, Davie JR, Shi Y, Hansen U, Margolis DM (2000) "The human factors YY1 and LSF repress the human immunodeficiency virus type 1 long terminal repeat via recruitment of histone deacetylase 1". J Virol 74(15):6790-6799

26. Cui M, Huang Y, Zhao Y, Zheng J (2009) "New insights for FOXO and cell-fate decision in HIV infection and HIV associated neurocognitive disorder". Adv Exp Med Biol 665:143-159

27. Deng G, Zhou G, Zhai Y, Li S, Li X, Li Y, Zhang R, Yao Z, Shen Y, Qiang B, Wang Y, He F (2004) Association of estrogen receptor a polymorphisms with susceptibility to chronic hepatitis B virus infection. Hepatology 40(2):318-326

28. Desforges M, Le Coupanec A, Dubeau P, Bourgouin A, Lajoie L, Dubé M, Talbot PJ (2019) "Human Coronaviruses and Other Respiratory Viruses: Underestimated Opportunistic Pathogens of the Central Nervous System?" Viruses 12(1)

29. Devaux CA, Rolain JM, Colson P, Raoult D (2020) "New insights on the antiviral effects of chloroquine against coronavirus: what to expect for COVID-19?". Int J Antimicrob Agents 55(5):105938

30. Doan KV, Kinyua AW, Yang DJ, Ko CM, Moh SH, Shong KE, Kim H, Park SK, Kim DH, Kim I, Paik JH, DePinho RA, Yoon SG, Kim IY, Seong JK, Choi YH, Kim KW (2016) "FoxO1 in dopaminergic neurons regulates energy homeostasis and targets tyrosine hydroxylase". Nat Commun 7:12733

31. Ester PP (2011) "Pathogenesis of congenital cytomegalovirus infection of the central nervous system". PERIODICUM BIOLOGORUM 113(1):51-60

32. Favreau DJ, Desforges M, St-Jean JR, Talbot PJ (2009) A human coronavirus OC43 variant harboring persistence-associated mutations in the $S$ glycoprotein differentially induces the unfolded protein response in human neurons as compared to wild-type virus. Virology 395(2):255-267

33. Feng Y, Fang Z, Liu B, Zheng X (2019) p38MAPK plays a pivotal role in the development of acute respiratory distress syndrome. Clinics 74:e509

34. Geng X, Huang C, Qin Y, McCombs J, Yuan Q, Harry B, Palmer A, Xia N-S, Xue D (2012) "Hepatitis B virus X protein targets $\mathrm{Bcl}-2$ proteins to increase intracellular calcium, required for virus replication and cell death induction." Proceedings of the National Academy of Sciences 109: 18471-18476

35. Ghigna MR, Reineke T, Rincé P, Schüffler P, El Mchichi B, Fabre M, Jacquemin E, Durrbach A, Samuel D, Joab I, Guettier C, Lucioni M, Paulli M, Tinguely M, Raphael M (2013) "Epstein-Barr Virus Infection and Altered Control of Apoptotic Pathways in Posttransplant Lymphoproliferative. Disorders" Pathobiology 80(2):53-59

36. Gianni T, Leoni V, Campadelli-Fiume G (2013) "Type I interferon and NF-kB activation elicited by herpes simplex virus $\mathrm{gH} / \mathrm{gL}$ via avß3 integrin in epithelial and neuronal cell lines". J Virol 87(24):13911-13916

37. Gianni T, Leoni V, Chesnokova L, Hutt-Fletcher L, Campadelli-Fiume G (2012) "avß3-integrin is a major sensor and activator of innate immunity to herpes simplex virus-1." Proceedings of the National Academy of Sciences of the United States of America 109

Page $17 / 42$ 
38. Grimes JM, Grimes KV (2020) "p38 MAPK inhibition: A promising therapeutic approach for COVID-19". J Mol Cell Cardiol 144:63-65

39. Guan Z, Shi N, Song Y, Zhang X, Zhang M, Duan M (2012) "Induction of the cellular microRNA-29c by influenza virus contributes to virus-mediated apoptosis through repression of antiapoptotic factors BCL2L2". Biochem Biophys Res Commun 425(3):662-667

40. Guo F, Yu X, Xu A, Xu J, Wang Q, Guo Y, Wu X, Tang Y, Ding Z, Zhang Y, Gong T, Pan Z, Li S, Kong L (2018) "Japanese encephalitis virus induces apoptosis by inhibiting Foxo signaling pathway." Veterinary Microbiology 220

41. Hartman ML, Czyz M (2020) BCL-w: apoptotic and non-apoptotic role in health and disease. Cell Death Dis 11(4):260

42. He Y, Casaccia-Bonnefil P (2008) "The Yin and Yang of YY1 in the nervous system". J Neurochem 106(4):1493-1502

43. Higashi T, Tanaka S, lida T, Okabe S (2018) "Synapse Elimination Triggered by BMP4 Exocytosis and Presynaptic BMP Receptor Activation. " Cell Reports 22(4):919-929

44. Huang B, West N, Vider J, Zhang P, Griffiths RE, Wolvetang E, Burtonclay P, Warrilow D (2019) "Inflammatory responses to a pathogenic West Nile virus strain". BMC Infect Dis 19(1):912

45. Huang C, Wang Y, Li X, Ren L, Zhao J, Hu Y, Zhang L, Fan G, Xu J, Gu X, Cheng Z, Yu T, Xia J, Wei Y, Wu W, Xie X, Yin W, Li H, Liu M, Xiao Y, Gao H, Guo L, Xie J, Wang G, Jiang R, Gao Z, Jin Q, Wang J, Cao B (2020) "Clinical features of patients infected with 2019 novel coronavirus in Wuhan. China" Lancet (London England) 395(10223):497-506

46. Huang da W, Sherman BT, Lempicki RA (2009) "Systematic and integrative analysis of large gene lists using DAVID bioinformatics resources". Nat Protoc 4(1):44-57

47. Huang H-Y, Lin Y-C-D, Li J, Huang K-Y, Shrestha S, Hong H-C, Tang Y, Chen Y-G, Jin C-N, Yu Y, Xu J-T, Li Y-M, Cai X-X, Zhou Z-Y, Chen X-H, Pei Y-Y, Hu L, Su J-J, Cui S-D, Wang F, Xie Y-Y, Ding S-Y, Luo M-F, Chou C-H, Chang N-W, Chen K-W, Cheng Y-H, Wan X-H, Hsu W-L, Lee T-Y, Wei F-X, Huang H-D (2020) "miRTarBase 2020: updates to the experimentally validated microRNA-target interaction database". Nucleic Acids Res 48(D1):D148D154

48. Hunt D, Raivich G, Anderson PN (2012) Activating transcription factor 3 and the nervous system. Front Mol Neurosci 5:7

49. Imamura O, Satoh Y, Endo S, Takishima K (2008) "Analysis of Extracellular Signal-Regulated Kinase 2 Function in Neural Stem/Progenitor Cells via Nervous System-Specific Gene Disruption". STEM CELLS 26(12):3247-3256

50. Islam O, Gong X, Rose-John S, Heese K (2009) "Interleukin-6 and neural stem cells: more than gliogenesis". Mol Biol Cell 20(1):188-199

51. Kasmi Y, Khataby K, Souiri A, Ennaji MM (2020) "Coronaviridae: 100,000 Years of Emergence and Reemergence." Emerging and Reemerging Viral Pathogens: 127-149

52. Kaul M, Lipton SA (2004) Signaling pathways to neuronal damage and apoptosis in human immunodeficiency virus type 1-associated dementia: Chemokine receptors, excitotoxicity, and beyond. J Neurovirol 10(Suppl 1):97-101

53. Kawashima H, Kashiwagi Y, loi H, Morichi S, Oana S, Yamanaka G, Takekuma K, Hoshika A, Sawai J, Kato Y (2012) "Production of chemokines in respiratory syncytial virus infection with central nervous system 
manifestations". J Infect Chemother 18(6):827-831

54. Kennedy AJ, Rahn EJ, Paulukaitis BS, Savell KE, Kordasiewicz HB, Wang J, Lewis JW, Posey J, Strange SK, Guzman-Karlsson MC, Phillips SE, Decker K, Motley ST, Swayze EE, Ecker DJ, Michael TP, Day JJ, Sweatt JD (2016) "Tcf4 Regulates Synaptic Plasticity, DNA Methylation, and Memory Function. " Cell Rep 16(10):26662685

55. Kennedy SH, Lam RW, McIntyre RS, Tourjman SV, Bhat V, Blier P, Hasnain M, Jollant F, Levitt AJ, MacQueen GM, Mclnerney SJ, Mclntosh D, Milev RV, Müller DJ, Parikh SV, Pearson NL, Ravindran AV, Uher R (2016) "Canadian Network for Mood and Anxiety Treatments (CANMAT) 2016 Clinical Guidelines for the Management of Adults with Major Depressive Disorder: Sect. 3. Pharmacological Treatments" Can J Psychiatry 61(9):540-560

56. Klotz U, Teml A, Schwab M (2007) "Clinical pharmacokinetics and use of infliximab". Clin Pharmacokinet 46(8):645-660

57. Kopitar-Jerala N (2015) "Innate Immune Response in Brain, NF-Kappa B Signaling and Cystatins." Frontiers in Molecular Neuroscience 8(73)

58. Kulkarni A, Scully TJ, O'Donnell LA (2017) "The antiviral cytokine interferon-gamma restricts neural stem/progenitor cell proliferation through activation of STAT1 and modulation of retinoblastoma protein phosphorylation". J Neurosci Res 95(8):1582-1601

59. Lange PS, Chavez JC, Pinto JT, Coppola G, Sun CW, Townes TM, Geschwind DH, Ratan RR (2008) "ATF4 is an oxidative stress-inducible, prodeath transcription factor in neurons in vitro and in vivo". J Exp Med 205(5):1227-1242

60. Laurence L, Brunton RH-D, Björn C, Knollmann (2018) Goodman \& Gilman's: The Pharmacological Basis of Therapeutics, 13th edn. McGraw-Hill Education

61. Leung L, Cahill CM (2010) TNF-alpha and neuropathic pain-a review. J Neuroinflammation 7:27

62. Li HB, Jin XQ, Jin X, Guo ZH, Ding XH, Wang Q, Liu RZ (2018) "BMP4 knockdown of NCSCs leads to aganglionosis in the middle embryonic stage". Mol Med Rep 17(4):5423-5427

63. Li Y, Fu L, Gonzales D, Lavi E (2004) Coronavirus Neurovirulence Correlates with the Ability of the Virus To Induce Proinflammatory Cytokine Signals from Astrocytes and Microglia. Journal of virology 78:3398-3406

64. Li Y, Li M, Wang M, Zhou Y, Chang J, Xian Y, Wang D, Mao L, Jin H, Hu B (2020) Acute cerebrovascular disease following COVID-19: a single center, retrospective, observational study. Stroke Vasc Neurol 5(3):279-284

65. Liguori C, Pierantozzi M, Spanetta M, Sarmati L, Cesta N, lannetta M, Ora J, Mina GG, Puxeddu E, Balbi O, Pezzuto G, Magrini A, Rogliani P, Andreoni M, Mercuri NB (2020) Subjective neurological symptoms frequently occur in patients with SARS-CoV2 infection. Brain Behav Immun 88:11-16

66. Liu J, Amar F, Corona C, So RWL, Andrews SJ, Nagy PL, Shelanski ML, Greene LA (2018) "Brain-Derived Neurotrophic Factor Elevates Activating Transcription Factor 4 (ATF4) in Neurons and Promotes ATF4Dependent Induction of Sesn2". Front Mol Neurosci 11:62

67. Liu Y, Yi Y, Wu W, Wu K, Zhang W (2019) "Bioinformatics prediction and analysis of hub genes and pathways of three types of gynecological cancer". Oncology letters 18(1):617-628

68. Liu, Y., M. Yu and D. Jiang (2019). "Downregulation of STAT1 induces the differentiation of neural stem cells through JNK pathway." Tissue \& cell 61: 61-66

69. Lizen B, Moens C, Mouheiche J, Sacré T, Ahn MT, Jeannotte L, Salti A, Gofflot F (2017) "Conditional Loss of Hoxa5 Function Early after Birth Impacts on Expression of Genes with Synaptic Function". Front Mol Neurosci 
$10: 369$

70. Lucas S (2016) "The Pharmacology of Indomethacin" Headache 56(2):436-446

71. Luchina N, Krivega I, Pankratova E (2003) "Human Oct-1L isoform has tissue-specific expression pattern similar to Oct-2. " Immunology letters 85:237-241

72. Ma SL, Tang NLS, Leung GTY, Fung AWT, Lam LCW (2014) "Estrogen Receptor a Polymorphisms and the Risk of Cognitive Decline: A 2-Year Follow-Up Study". The American Journal of Geriatric Psychiatry 22(5):489-498

73. Mahlakõiv T, Ritz D, Mordstein M, DeDiego ML, Enjuanes L, Müller MA, Drosten C, Staeheli P (2012) "Combined action of type I and type III interferon restricts initial replication of severe acute respiratory syndrome coronavirus in the lung but fails to inhibit systemic virus spread". J Gen Virol 93(Pt 12):2601-2605

74. Majidi SP, Reddy NC, Moore MJ, Chen H, Yamada T, Andzelm MM, Cherry TJ, Hu LS, Greenberg ME, Bonni A (2019) "Chromatin Environment and Cellular Context Specify Compensatory Activity of Paralogous MEF2 Transcription Factors. " Cell Reports 29(7):2001-2015.e2005

75. Mamoor S (2020) The DNA Damage Inducible Transcript DDIT3 is differentially expressed and transcriptionally induced in models of coronavirus infection

76. Mao L, Jin H, Wang M, Hu Y, Chen S, He Q, Chang J, Hong C, Zhou Y, Wang D, Miao X, Li Y, Hu B (2020) "Neurologic Manifestations of Hospitalized Patients With Coronavirus Disease 2019 in Wuhan, China". JAMA Neurol 77(6):683-690

77. Masgutova G, Harris A, Jacob B, Corcoran LM, Clotman F (2019) "Pou2f2 Regulates the Distribution of Dorsal Interneurons in the Mouse Developing Spinal Cord." Frontiers in Molecular Neuroscience 12(263)

78. Mathew S, Faheem M, Ibrahim SM, Iqbal W, Rauff B, Fatima K, Qadri I (2016) "Hepatitis C virus and neurological damage". World J Hepatol 8(12):545-556

79. Mazalouskas M, Jessen T, Varney S, Sutcliffe JS, Veenstra-VanderWeele J, Cook EH and A. M. D. Carneiro (2015) "Integrin $\beta 3$ Haploinsufficiency Modulates Serotonin Transport and Antidepressant-Sensitive Behavior in Mice." Neuropsychopharmacology 40(8): 2015-2024

80. McLaughlin-Drubin ME, Huh K-W, Münger K (2008) "Human Papillomavirus Type 16 E7 Oncoprotein Associates with E2F6". J Virol 82(17):8695

81. Mease PJ (2007) Adalimumab in the treatment of arthritis. Ther Clin Risk Manag 3(1):133-148

82. Mitchell WJ (1995) "Neurons differentially control expression of a herpes simplex virus type 1 immediateearly promoter in transgenic mice". J Virol 69(12):7942-7950

83. Mitchell WJ, De Santo RJ, Zhang SD, Odenwald WF, Arnheiter H (1993) "Herpes simplex virus pathogenesis in transgenic mice is altered by the homeodomain protein Hox 1.3". J Virol 67(8):4484-4491

84. Morfopoulou S, Brown JR, Davies EG, Anderson G, Virasami A, Qasim W, Chong WK, Hubank M, Plagnol V, Desforges M, Jacques TS, Talbot PJ, Breuer J (2016) "Human Coronavirus OC43 Associated with Fatal Encephalitis". N Engl J Med 375(5):497-498

85. Morichi S, Morishita N, Ishida Y, Oana S, Yamanaka G, Kashiwagi Y, Kawashima H (2017) Examination of neurological prognostic markers in patients with respiratory syncytial virus-associated encephalopathy. Int $\mathrm{J}$ Neurosci 127(1):44-50

86. Nabirotchkin SP, Bouaziz AE, Cohen J, D (2020) "Focusing on the Unfolded Protein Response and Autophagy Related Pathways to Reposition Common Approved Drugs against COVID-19." Preprints 
87. Nakanishi M, Niidome T, Matsuda S, Akaike A, Kihara T, Sugimoto H (2007) Microglia-derived interleukin-6 and leukaemia inhibitory factor promote astrocytic differentiation of neural stem/progenitor cells. Eur $\mathrm{J}$ Neurosci 25(3):649-658

88. Nencioni L, De Chiara G, Sgarbanti R, Amatore D, Aquilano K, Marcocci ME, Serafino A, Torcia M, Cozzolino F, Ciriolo MR, Garaci E, Palamara AT (2009) "Bcl-2 expression and p38MAPK activity in cells infected with influenza A virus: impact on virally induced apoptosis and viral replication". J Biol Chem 284(23):1600416015

89. Niu J, Shen L, Huang B, Ye F, Zhao L, Wang H, Deng Y, Tan W (2020) Non-invasive bioluminescence imaging of HCoV-OC43 infection and therapy in the central nervous system of live mice. Antiviral Res 173:104646

90. O'Shea JJ, Schwartz DM, Villarino AV, Gadina M, Mclnnes IB, Laurence A (2015) The JAK-STAT pathway: impact on human disease and therapeutic intervention. Annu Rev Med 66:311-328

91. Oh J, McCloskey MA, Blong CC, Bendickson L, Nilsen-Hamilton M, Sakaguchi DS (2010) "Astrocyte-derived interleukin-6 promotes specific neuronal differentiation of neural progenitor cells from adult hippocampus". J Neurosci Res 88(13):2798-2809

92. Ojha CR, Rodriguez M, Karuppan MKM, Lapierre J, Kashanchi F, El-Hage N (2019) "Toll-like receptor 3 regulates Zika virus infection and associated host inflammatory response in primary human astrocytes". PLOS ONE 14(2):e0208543

93. Park J, Kang W, Ryu S-W, Kim W-I, Chang D-Y, Lee D, Park DY, Choi Y-H, Choi K, Shin E-C, Choi C (2012) "Hepatitis $\mathrm{C}$ virus infection enhances TNFa-induced cell death via suppression of NF-kB." Hepatology (Baltimore. Md) 56:831-840

94. Pasieka TJ, Cilloniz C, Carter VS, Rosato P, Katze MG, Leib DA (2011) "Functional genomics reveals an essential and specific role for Stat1 in protection of the central nervous system following herpes simplex virus corneal infection". J Virol 85(24):12972-12981

95. Pearce AF, Lyles DS (2009) "Vesicular stomatitis virus induces apoptosis primarily through Bak rather than Bax by inactivating Mcl-1 and Bcl-XL". J Virol 83(18):9102-9112

96. Pennycook BR, Vesela E, Peripolli S, Singh T, Barr AR, Bertoli C, de Bruin RAM (2020) "E2F-dependent transcription determines replication capacity and S phase length". Nat Commun 11(1):3503

97. Perlman S, Netland J (2009) "Coronaviruses post-SARS: update on replication and pathogenesis". Nat Rev Microbiol 7(6):439-450

98. Pierre J, Talbot MD, Brison E, Hélène Jacomy (2011) Coronaviruses as Encephalitis - Inducing Infectious Agents, in Non-Flavivirus Encephalitis. S. Tkachev, IntechOpen

99. Plantone D, Koudriavtseva T (2018) "Current and Future Use of Chloroquine and Hydroxychloroquine in Infectious, Immune, Neoplastic, and Neurological Diseases: A Mini-Review. " Clin Drug Investig 38(8):653-671

100. Potthast H, Dressman JB, Junginger HE, Midha KK, Oeser H, Shah VP, Vogelpoel H, Barends DM (2005) "Biowaiver monographs for immediate release solid oral dosage forms: ibuprofen". J Pharm Sci 94(10):2121-2131

101. Pozo K, Cingolani LA, Bassani S, Laurent F, Passafaro M, Goda Y (2012) $\beta 3$ integrin interacts directly with GluA2 AMPA receptor subunit and regulates AMPA receptor expression in hippocampal neurons. Proc Natl Acad Sci U S A 109(4):1323-1328

102. Puccini JM, Ruller CM, Robinson SM, Knopp KA, Buchmeier MJ, Doran KS, Feuer R (2014) Distinct neural stem cell tropism, early immune activation, and choroid plexus pathology following coxsackievirus infection 
in the neonatal central nervous system. Lab Invest 94(2):161-181

103. Ragel BT, Couldwell WT, Gillespie DL, Jensen RL (2007) "Identification of hypoxia-induced genes in a malignant glioma cell line (U-251) by cDNA microarray analysis". Neurosurg Rev 30(3):181-187

104. Reichardt LF (2006) Neurotrophin-regulated signalling pathways. Philos Trans R Soc Lond B Biol Sci 361(1473):1545-1564

105. Renault VM, Rafalski VA, Morgan AA, Salih DA, Brett JO, Webb AE, Villeda SA, Thekkat PU, Guillerey C, Denko NC, Palmer TD, Butte AJ, Brunet A (2009) "FoxO3 regulates neural stem cell homeostasis". Cell Stem Cell 5(5):527-539

106. Rothan HA, Byrareddy SN (2020) "The epidemiology and pathogenesis of coronavirus disease (COVID-19) outbreak. " J Autoimmun 109:102433

107. Ryan AK, Rosenfeld MG (1997) "POU domain family values: flexibility, partnerships, and developmental codes". Genes Dev 11(10):1207-1225

108. Sabroe I, Parker LC, Dower SK, Whyte MK (2008) "The role of TLR activation in inflammation". J Pathol 214(2):126-135

109. Santo EE, Paik J (2018) FOXO in Neural Cells and Diseases of the Nervous System. Curr Top Dev Biol 127:105-118

110. Schäffner I, Minakaki G, Khan MA, Balta EA, Schlötzer-Schrehardt U, Schwarz TJ, Beckervordersandforth R, Winner B, Webb AE, DePinho RA, Paik J, Wurst W, Klucken J, Lie DC (2018) "FoxO Function Is Essential for Maintenance of Autophagic Flux and Neuronal Morphogenesis in Adult Neurogenesis. " Neuron 99(6):11881203.e1186

111. Selinger M, Wilkie GS, Tong L, Gu Q, Schnettler E, Grubhoffer L, Kohl A (2017) Analysis of tick-borne encephalitis virus-induced host responses in human cells of neuronal origin and interferon-mediated protection. J Gen Virol 98(8):2043-2060

112. Sen D, Balakrishnan B, Jayandharan GR (2014) "Cellular unfolded protein response against viruses used in gene therapy." Frontiers in Microbiology 5(250)

113. Serrano-Castro PJ, Estivill-Torrús G, Cabezudo-García P, Reyes-Bueno JA, Ciano Petersen N, Aguilar-Castillo MJ, Suárez-Pérez J, Jiménez-Hernández MD, Moya-Molina M, Oliver-Martos B, Arrabal-Gómez C and F. Rodríguez de Fonseca (2020) "Impact of SARS-CoV-2 infection on neurodegenerative and neuropsychiatric diseases: a delayed pandemic?" Neurologia 35(4): 245-251

114. Shannon P, Markiel A, Ozier O, Baliga NS, Wang JT, Ramage D, Amin N, Schwikowski B, Ideker T (2003) "Cytoscape: a software environment for integrated models of biomolecular interaction networks". Genome Res 13(11):2498-2504

115. Sims SG, Meares GP (2019) "Janus Kinase 1 Is Required for Transcriptional Reprograming of Murine Astrocytes in Response to Endoplasmic Reticulum Stress." Frontiers in Cellular Neuroscience 13(446)

116. Suzuki Kurokawa M, Suzuki N (2004) "Behcet's disease". Clin Exp Med 4(1):10-20

117. Tambasco-Studart M, Titiz O, Raschle T, Forster G, Amrhein N, Fitzpatrick TB (2005) Vitamin B6 biosynthesis in higher plants. Proc Natl Acad Sci U S A 102(38):13687-13692

118. Tan YX, Tan TH, Lee MJ, Tham PY, Gunalan V, Druce J, Birch C, Catton M, Fu NY, Yu VC, Tan YJ (2007) "Induction of apoptosis by the severe acute respiratory syndrome coronavirus 7a protein is dependent on its interaction with the Bcl-XL protein". J Virol 81(12):6346-6355 
119. Tardif KD, Mori K, Kaufman RJ, Siddiqui A (2004) "Hepatitis C virus suppresses the IRE1-XBP1 pathway of the unfolded protein response". J Biol Chem 279(17):17158-17164

120. Tergaonkar V (2006) NFkappaB pathway: a good signaling paradigm and therapeutic target. Int J Biochem Cell Biol 38(10):1647-1653

121. Tergaonkar V, Correa RG, Ikawa M, Verma IM (2005) "Distinct roles of IkappaB proteins in regulating constitutive NF-kappaB activity". Nat Cell Biol 7(9):921-923

122. The Gene Ontology Consortium (2019) The Gene Ontology Resource: 20 years and still GOing strong. Nucleic Acids Res 47(D1):D330-D338

123. Tolou-Ghamari Z, Zare M, Habibabadi JM, Najafi MR (2013) A quick review of carbamazepine pharmacokinetics in epilepsy from 1953 to 2012. J Res Med Sci 18(Suppl 1):S81-S85

124. Totura AL, Whitmore A, Agnihothram S, Schäfer A, Katze MG, Heise MT, Baric RS (2015) "Toll-Like Receptor 3 Signaling via TRIF Contributes to a Protective Innate Immune Response to Severe Acute Respiratory. Syndrome Coronavirus Infection" mBio 6(3):e00638-e00615

125. Varney S, Polston KF, Jessen T, Carneiro AM (2015) Mice lacking integrin $\beta 3$ expression exhibit altered response to chronic stress. Neurobiol Stress 2:51-58

126. Versteeg GA, van de Nes PS, Bredenbeek PJ, Spaan WJM (2007) "The Coronavirus Spike Protein Induces Endoplasmic Reticulum Stress and Upregulation of Intracellular Chemokine mRNA Concentrations". J Virol 81(20):10981

127. Vincent MJ, Bergeron E, Benjannet S, Erickson BR, Rollin PE, Ksiazek TG, Seidah NG, Nichol ST (2005) "Chloroquine is a potent inhibitor of SARS coronavirus infection and spread". Virol J 2:69

128. Wan S, Yi Q, Fan S, Lv J, Zhang X, Guo L, Lang C, Xiao Q, Xiao K, Yi Z, Qiang M, Xiang J, Zhang B, Chen Y (2020) Characteristics of lymphocyte subsets and cytokines in peripheral blood of 123 hospitalized patients with 2019 novel coronavirus pneumonia (NCP)

129. Wang D, Hu B, Hu C, Zhu F, Liu X, Zhang J, Wang B, Xiang H, Cheng Z, Xiong Y, Zhao Y, Li Y, Wang X, Peng Z (2020) "Clinical Characteristics of 138 Hospitalized Patients With 2019 Novel Coronavirus-Infected Pneumonia in Wuhan. China" Jama 323(11):1061-1069

130. Wang GZ, Goff SP (2020) Yin Yang 1 is a potent activator of human T lymphotropic virus type 1 LTR-driven gene expression via RNA binding. Proc Natl Acad Sci U S A 117(31):18701-18710

131. Wang M, Cao R, Zhang L, Yang X, Liu J, Xu M, Shi Z, Hu Z, Zhong W, Xiao G (2020) "Remdesivir and chloroquine effectively inhibit the recently emerged novel coronavirus (2019-nCoV) in vitro". Cell Res 30(3):269-271

132. Wang X, Choi JH, Ding J, Yang L, Ngoka LC, Lee EJ, Zha Y, Mao L, Jin B, Ren M, Cowell J, Huang S, Shi H, Cui H, Ding HF (2013) HOXC9 directly regulates distinct sets of genes to coordinate diverse cellular processes during neuronal differentiation. BMC Genom 14:830

133. Watashi K, Inoue D, Hijikata M, Goto K, Aly HH, Shimotohno K (2007) "Anti-hepatitis C virus activity of tamoxifen reveals the functional association of estrogen receptor with viral RNA polymerase NS5B". J Biol Chem 282(45):32765-32772

134. Wernicke S, Rasche F (2006) FANMOD: a tool for fast network motif detection. Bioinformatics 22(9):11521153

135. Wingender E (2008) The TRANSFAC project as an example of framework technology that supports the analysis of genomic regulation. Brief Bioinform 9(4):326-332

Page 23/42 
136. Winkelmann ER, Luo H, Wang T (2016) "West Nile Virus Infection in the Central Nervous System." F1000Res 5

137. Wishart DS, Feunang YD, Guo AC, Lo EJ, Marcu A, Grant JR, Sajed T, Johnson D, Li C, Sayeeda Z, Assempour N, lynkkaran I, Liu Y, Maciejewski A, Gale N, Wilson A, Chin L, Cummings R, Le D, Pon A, Knox C, Wilson M (2018) DrugBank 5.0: a major update to the DrugBank database for 2018. Nucleic Acids Res 46(D1):D1074Dd1082

138. Wong ET, Tergaonkar V (2009) Roles of NF-kappaB in health and disease: mechanisms and therapeutic potential. Clin Sci (Lond) 116(6):451-465

139. Wu T, Donohoe ME (2019) "Yy1 regulates Senp1 contributing to AMPA receptor GluR1 expression following neuronal depolarization". J Biomed Sci 26(1):79

140. Yang L, Lindholm K, Konishi Y, Li R, Shen Y (2002) "Target depletion of distinct tumor necrosis factor receptor subtypes reveals hippocampal neuron death and survival through different signal transduction pathways". J Neurosci 22(8):3025-3032

141. Yang S, Fu C, Lian X, Dong X, Zhang Z (2019) "Understanding Human-Virus Protein-Protein Interactions Using a Human Protein Complex-Based Analysis Framework." mSystems 4(2)

142. Yang TH, Wu TH, Chang YL, Liao HT, Hsu CC, Tsai CY, Chou YC (2018) "Cyclosporine for the treatment of lupus nephritis in patients with systemic lupus erythematosus". Clin Nephrol 89(4):277-285

143. Yang X, Yu Y, Xu J, Shu H, Xia J, Liu H, Wu Y, Zhang L, Yu Z, Fang M, Yu T, Wang Y, Pan S, Zou X, Yuan S, Shang $Y(2020)$ Clinical course and outcomes of critically ill patients with SARS-CoV-2 pneumonia in Wuhan, China: a single-centered, retrospective, observational study. Lancet Respir Med 8(5):475-481

144. Yeh EA, Collins A, Cohen ME, Duffner PK, Faden H (2004) Detection of coronavirus in the central nervous system of a child with acute disseminated encephalomyelitis. Pediatrics 113(1 Pt 1):e73-e76

145. Yndart A, Kaushik A, Agudelo M, Raymond A, Atluri VS, Saxena SK, Nair M (2015) "Investigation of Neuropathogenesis in HIV-1 Clade B and C Infection Associated with IL-33 and ST2 Regulation". ACS Chem Neurosci 6(9):1600-1612

146. Zan J, Zhang H, Gu A-P, Zhong K-L, Lu M-Y, Bai X-X, Zhang J, Cai J (2017) Yin Yang 1 Dynamically Regulates Antiviral Innate Immune Responses During Viral Infection. Cell Physiol Biochem 44:607-617

147. Zhai Y, Zhou G, Deng G, Xie W, Dong X, Zhang X, Yu L, Yang H, Yuan X, Zhang H, Zhi L, Yao Z, Shen Y, Qiang B, He F (2006) "Estrogen receptor alpha polymorphisms associated with susceptibility to hepatocellular carcinoma in hepatitis B virus carriers. " Gastroenterology 130(7):2001-2009

148. Zhao C, Zhao W (2020) "NLRP3 Inflammasome-A Key Player in Antiviral Responses. " Front Immunol 11:211

149. Zhou Y, Hou Y, Shen J, Huang Y, Martin W, Cheng F (2020) "Network-based drug repurposing for novel coronavirus 2019-nCoV/SARS-CoV-2. " Cell Discovery 6(1):14

150. Zhu B, Carmichael RE, Solabre Valois L, Wilkinson KA, Henley JM (2018) The transcription factor MEF2A plays a key role in the differentiation/maturation of rat neural stem cells into neurons. Biochem Biophys Res Commun 500(3):645-649

151. Zolova OE, Wight PA (2011) "YY1 Negatively Regulates Mouse Myelin Proteolipid Protein (PLP1) Gene Expression in Oligodendroglial Cells". ASN Neuro 3(4):AN20110021

152. Zumla A, Chan JFW, Azhar El, Hui DSC, Yuen K-Y (2016) Coronaviruses - drug discovery and therapeutic options. Nat Rev Drug Discovery 15(5):327-347 


\section{Tables}

Table1. The number of differentially expressed genes related to the HCoV-OC43 microarray dataset and RNA-seq analysis of two cell lines infected with SARS-CoV-2.

\begin{tabular}{|lll|}
\hline & $\begin{array}{l}\text { Up-regulated genes } \\
\left(\log _{2} \mathrm{FC}>0.5\right)\end{array}$ & $\begin{array}{l}\text { Down-regulated genes } \\
\left(\log _{2} \mathrm{FC}<-0.5\right)\end{array}$ \\
\hline GSE13879 (24h) & 2264 & 833 \\
\hline GSE13879 & 537 & 845 \\
(shared between 48h\&72h) & & \\
\hline NHBE cell line & 250 & 190 \\
\hline A549 cell line & 351 & 101 \\
\hline
\end{tabular}

Table2. Number of nodes and edges in each PPI network.

\begin{tabular}{|llll|}
\hline & PPI network of each input & Number of nodes & Number of edges \\
\hline HCoV-0C43 & Up-regulated genes & 2323 & 8438 \\
\cline { 2 - 4 }$(24 \mathrm{~h})$ & Down-regulated genes & 855 & 2136 \\
\hline HCoV-0C43 & Up-regulated genes & 551 & 1550 \\
$(48$ \& $82 \mathrm{~h})$ & Down-regulated genes & 882 & 1322 \\
\cline { 2 - 3 } SARS-CoV-2 & Up-regulated genes & 578 & 1709 \\
\cline { 2 - 4 } & Down-regulated genes & 290 & 163 \\
& & & \\
\hline
\end{tabular}

Table3. Summary of the number of four regulatory relationship types among miRNAs, genes, and TFs. 


\begin{tabular}{|c|c|c|c|c|c|}
\hline Input type & Relationships & $\begin{array}{l}\text { Number } \\
\text { of pairs }\end{array}$ & $\begin{array}{l}\text { Number } \\
\text { of genes }\end{array}$ & $\begin{array}{c}\text { Number } \\
\text { of TFs }\end{array}$ & $\begin{array}{l}\text { Number } \\
\text { of miRs }\end{array}$ \\
\hline \multirow{4}{*}{$\begin{array}{l}\text { Up-regulated genes of } \\
\text { GSE related to } \\
\text { HCoV-OC43 }\end{array}$} & $\mathrm{TF} \rightarrow$ gene & 8471 & 516 & 263 & - \\
\hline & $\mathrm{miR} \rightarrow$ gene & 10280 & 404 & 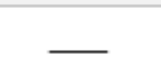 & 1594 \\
\hline & $\mathrm{TF} \rightarrow \mathrm{miR}$ & 2044 & - & 356 & 335 \\
\hline & $\mathrm{miR} \rightarrow \mathrm{TF}$ & 9045 & - & 229 & 1556 \\
\hline \multirow{4}{*}{$\begin{array}{c}\text { Down-regulated genes } \\
\text { of GSE related to } \\
\mathrm{HCoV}-\mathrm{OC} 43\end{array}$} & $\mathrm{TF} \rightarrow$ gene & 12672 & 798 & 298 & 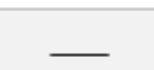 \\
\hline & $\mathrm{miR} \rightarrow$ gene & 20184 & 657 & - & 1688 \\
\hline & $\mathrm{TF} \rightarrow \mathrm{miR}$ & 2092 & - & 356 & 339 \\
\hline & $\mathrm{miR} \rightarrow \mathrm{TF}$ & 10188 & - & 262 & 1584 \\
\hline \multirow{4}{*}{$\begin{array}{l}\text { Up-regulated genes of } \\
\text { RNA sequencing } \\
\text { results of SARS-CoV- } \\
2 \text { infected cell lines }\end{array}$} & $\mathrm{TF} \rightarrow$ gene & 9051 & 529 & 313 & - \\
\hline & $\mathrm{miR} \rightarrow$ gene & 10018 & 437 & - & 1572 \\
\hline & $\mathrm{TF} \rightarrow \mathrm{miR}$ & 2077 & - & 357 & 338 \\
\hline & $\mathrm{miR} \rightarrow \mathrm{TF}$ & 20682 & - & 277 & 1599 \\
\hline \multirow{4}{*}{$\begin{array}{l}\text { Down-regulated genes } \\
\text { of RNA sequencing } \\
\text { results of SARS-CoV- } \\
2 \text { infected cell lines }\end{array}$} & $\mathrm{TF} \rightarrow$ gene & 4267 & 256 & 237 & - \\
\hline & $\mathrm{miR} \rightarrow$ gene & 4721 & 190 & 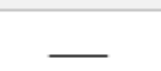 & 1365 \\
\hline & $\mathrm{TF} \rightarrow \mathrm{miR}$ & 2038 & - & 355 & 331 \\
\hline & $\mathrm{miR} \rightarrow \mathrm{TF}$ & 8283 & 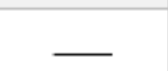 & 204 & 1534 \\
\hline
\end{tabular}

Table 4. Top shared biological processes between enrichment results of GRN \& PPI networks of each gene set. 


\section{selected up-regulated genes of GSE related to HCoV-OC43 \\ selected down-regulated genes of GSE related to $\mathrm{HCOV}-0 \mathrm{C} 43$}

nuclear-transcribed mRNA catabolic process

nonsense-mediated decay

SRP-dependent cotranslational protein targeting to membrane

nuclear-transcribed mRNA catabolic process

translation

mRNA metabolic process

establishment of protein localization to membrane

peptide metabolic process

protein targeting

establishment of protein

localization to organelle protein poly-ubiquitination

protein ubiquitination

protein modification by small

protein conjugation or removal

tRNA aminoacylation for protein translation

cellular protein metabolic process

NIK/NF-kappaB signaling, cellular response to organic substance

cellular response to organic substance

response to virus

response to organic substance

response to stress selected up-regulated genes of RNA sequencing results of SARS-CoV-2 infected cell lines

defense response

cytokine-mediated signaling pathway

immune response

response to other organisms

type I interferon signaling pathway

innate immune response

response to cytokine

cellular response to cytokine stimulus

immune system process

response to stress

Table 5. Top shared KEGG pathways between enrichment results of GRN \& PPI networks of each gene set.

\section{selected up-regulated genes of GSE related to HCoV- $0 \mathrm{C43}$}

Ribosome

Oxidative phosphorylation

Parkinson's disease

Non-alcoholic fatty liver disease (NAFLD)

Alzheimer's disease

mRNA metabolic process

Huntington's disease

Spliceosome

Pathogenic Escherichia coli infection

\section{selected down-regulated genes of GSE related to HCoV-OC43}

Aminoacyl-tRNA biosynthesis

TNF signaling pathway

NOD-like receptor signaling pathway

NF-kappa B signaling pathway

Toxoplasmosis

Measles selected up-regulated genes of RNA sequencing results of SARS-CoV-2 infected cell lines

Influenza A

Herpes simplex infection

NOD-like receptor signaling pathway

Rheumatoid arthritis

Measles

TNF signaling pathway

Hepatitis C

Pertussis

Cytokine-cytokine receptor interaction

Legionellosis 
Table 6. The table represents the hub/bottleneck nodes available among the 31 crucial shared genes of the intersection of merged motifs in the two GRN networks of up-regulated genes. The most critical genes are bolded.

\begin{tabular}{|c|c|c|c|c|c|c|c|c|}
\hline $\begin{array}{l}\text { Gene } \\
\text { name }\end{array}$ & $\begin{array}{l}\text { Hub } \\
\text { genes in } \\
\text { both } \\
\text { GRN } \\
\text { networks }\end{array}$ & $\begin{array}{l}\text { Hub } \\
\text { genes in } \\
\text { one of } \\
\text { GRN } \\
\text { networks }\end{array}$ & $\begin{array}{l}\text { Bottleneck } \\
\text { genes in } \\
\text { both GRN } \\
\text { networks }\end{array}$ & $\begin{array}{l}\text { Bottleneck } \\
\text { genes in } \\
\text { one of } \\
\text { GRN } \\
\text { networks }\end{array}$ & $\begin{array}{l}\text { Hub } \\
\text { genes in } \\
\text { one of } \\
\text { the PPI } \\
\text { networks }\end{array}$ & $\begin{array}{l}\text { Bottleneck } \\
\text { genes in } \\
\text { one of the } \\
\text { PPI } \\
\text { networks }\end{array}$ & $\begin{array}{l}\text { MCODE } \\
\text { cluster in } \\
\text { one of } \\
\text { PPI } \\
\text { networks }\end{array}$ & $\begin{array}{l}\text { Seed } \\
\text { gene }\end{array}$ \\
\hline ZFHX3 & + & + & + & + & & & & \\
\hline HOXA5 & + & + & + & + & & + & + & \\
\hline POU2F2 & + & + & + & + & & & + & \\
\hline HIF1A & + & + & + & + & & & & \\
\hline MAZ & + & + & + & + & & & & \\
\hline POU3F1 & & + & & + & & & & \\
\hline LIN28B & & + & & + & & & & \\
\hline TNF & & + & & + & + & + & + & \\
\hline ITGB3 & & + & & + & & & + & \\
\hline FOSL1 & & + & & + & & & & \\
\hline STAT1 & & + & & + & + & + & + & + \\
\hline IL6 & & + & & + & + & + & & \\
\hline PRDM1 & & + & & + & & & & \\
\hline SAMD9L & & & & + & & & & \\
\hline BMP2 & & & & + & & & & \\
\hline RELB & & + & & & & & & \\
\hline USF1 & & + & & & & & & \\
\hline RBMX & & & & & + & & + & \\
\hline NFKB2 & & & & & + & + & & \\
\hline IRF9 & & & & & + & & + & \\
\hline IRF7 & & & & & + & + & + & \\
\hline IL1B & & & & & + & + & + & \\
\hline PBX1 & & & & & & + & & \\
\hline PLAU & & & & & & & + & \\
\hline SPRR2A & & & & & & & + & \\
\hline
\end{tabular}


Table 7. The table represents the hub/bottleneck nodes available among the 35 crucial shared genes of the intersection of merged motifs in the two GRN networks of down-regulated genes. The most critical genes are bolded.

\begin{tabular}{|c|c|c|c|c|c|c|c|c|}
\hline $\begin{array}{l}\text { Gene } \\
\text { name }\end{array}$ & $\begin{array}{l}\text { Hub } \\
\text { genes in } \\
\text { both } \\
\text { GRN } \\
\text { networks }\end{array}$ & $\begin{array}{l}\text { Hub } \\
\text { genes in } \\
\text { one of } \\
\text { GRN } \\
\text { networks }\end{array}$ & $\begin{array}{l}\text { Botteleneck } \\
\text { genes in } \\
\text { both GRN } \\
\text { networks }\end{array}$ & $\begin{array}{l}\text { Bottleneck } \\
\text { genes in } \\
\text { one of } \\
\text { GRN } \\
\text { networks }\end{array}$ & $\begin{array}{l}\text { Hub } \\
\text { genes in } \\
\text { one of } \\
\text { the PPI } \\
\text { networks }\end{array}$ & $\begin{array}{l}\text { Bottleneck } \\
\text { genes in } \\
\text { one of the } \\
\text { PPI } \\
\text { networks }\end{array}$ & $\begin{array}{l}\text { MCODE } \\
\text { cluster in } \\
\text { one of } \\
\text { PPI } \\
\text { networks }\end{array}$ & $\begin{array}{l}\text { Seed } \\
\text { gene }\end{array}$ \\
\hline YY1 & + & + & + & + & & & + & + \\
\hline LEF1 & + & + & + & + & & & & \\
\hline E2F6 & + & + & + & + & + & & + & \\
\hline GATA6 & + & + & + & + & & & & \\
\hline ZBTB7A & + & + & + & + & & & & \\
\hline ESR1 & + & + & + & + & + & + & + & \\
\hline KLF13 & + & + & + & + & & & & \\
\hline F0X03 & + & + & + & + & + & + & & \\
\hline MEF2A & + & + & + & + & + & + & + & \\
\hline ETS1 & + & + & + & + & & & & \\
\hline TCF4 & + & + & + & + & + & + & & \\
\hline F0X01 & & & + & + & + & + & + & \\
\hline ATF3 & & + & & + & + & + & + & \\
\hline BCL2L2 & & + & & & & & + & + \\
\hline ATF4 & & + & & + & + & + & + & \\
\hline TP63 & & + & & + & & & & \\
\hline BMP4 & & + & & & + & + & & \\
\hline APEX1 & & + & & + & & & & \\
\hline MTF1 & & + & & + & & & & \\
\hline BMP4 & & & & + & & & & \\
\hline DDIT3 & & & & + & + & + & & \\
\hline CBFB & & & & & + & + & & \\
\hline XBP1 & & & & & + & + & + & \\
\hline CRTC3 & & & & & & + & & \\
\hline SAMD9L & & & & & & & + & \\
\hline
\end{tabular}


Table 8. The categorization of the most crucial repurposed medications.

\begin{tabular}{|c|c|c|}
\hline Categorization & drugs & $\begin{array}{l}\text { Target } \\
\text { genes }\end{array}$ \\
\hline $\begin{array}{l}\text { Drugs that affect the } \\
\text { nervous system }\end{array}$ & $\begin{array}{l}\text { - risperidone, } \\
\text { - ibudilast, } \\
\text { - carbamazepine, } \\
\text { - midazolam, } \\
\text { - pyridoxine, } \\
\text { - duloxetine, } \\
\text { - melatonin, } \\
\text { - rizatriptan, } \\
\text { - SSRIs }\end{array}$ & $\begin{array}{l}\text { TNF-a, } \\
\text { IL-6, } \\
\text { ESR1, } \\
\text { FOX01, } \\
\text { ATF3 }\end{array}$ \\
\hline $\begin{array}{l}\text { immunosuppressive or } \\
\text { immunomodulatory } \\
\text { drugs }\end{array}$ & $\begin{array}{l}\text { etanercept, adalimumab, infliximab, golimumab, certolizumab, } \\
\text { pomalidomide, talactoferrin alfa, placulumab, pirfenidone, pentoxifylline, } \\
\text { onercept, afelimomab, ozoralizumab, pegsunercept, hydroxychloroquine, } \\
\text { chloroquine, apremilast, talmapimod, ibudilast, cyclosporine, } \\
\text { mycophenolate mofetil, siltuximab, ginseng, sirukumab, olokizumab, } \\
\text { clazakizumab, (peg) interferon alfa-2b, ifosfamide, peginterferon alfa-2a, } \\
\text { rituximab, tacrolimus, antithymocyte immunoglobulin, aspirin, } \\
\text { prasterone (DHEA), everolimus, leflunomide, cyclophosphamide, } \\
\text { bortezomib, ibuprofen, penicillamine, indomethacin , Sirolimus, } \\
\text { Diclofenac, Celecoxib }\end{array}$ & $\begin{array}{l}\text { TNF-A, } \\
\text { IL-6, } \\
\text { ITGB3 } \\
\text { ESR1, } \\
\text { FOXO1, } \\
\text { BCL2L2 }\end{array}$ \\
\hline Anti-viral drugs & $\begin{array}{l}\text { hydroxychloroquine, chloroquine, abacavir, didanosine, stavudine, } \\
\text { interferon alfa-2b, saquinavir, nelfinavir, peginterferon alfa-2a, ribavirin }\end{array}$ & $\begin{array}{l}\text { TNF-a, } \\
\text { IL-6 }\end{array}$ \\
\hline $\begin{array}{l}\text { Shared drugs with } \\
\text { clinical trials on SARS- } \\
\text { CoV-2 }\end{array}$ & $\begin{array}{l}\text { arsenic trioxide, clazakizumab, rabeprazole, pyridoxine, nelfinavir, } \\
\text { thalidomide, pirfenidone, hydroxychloroquine, tirofiban, olokizumab, } \\
\text { midazolam, etanercept, lenalidomide, cyclosporine, omeprazole, } \\
\text { spironolactone, atorvastatin, ibudilast, peginterferon alfa-2a, infliximab, } \\
\text { adalimumab, metronidazole, tacrolimus, siltuximab, apremilast, } \\
\text { clopidogrel, sirukumab, interferon alfa-2b, levofloxacin, pentoxifylline, } \\
\text { talactoferrin alfa, folic acid, ribavirin, nafamostat, chloroquine, estradiol, } \\
\text { genistein, melatonin, iodine, doxycycline, tamoxifen, vitamin e, } \\
\text { leflunomide, progesterone, curcumin, etoposide, fenretinide, suramin, } \\
\text { hydrogen peroxide, ibuprofen, sirolimus, indomethacin, } \\
\text { deferoxamine, celecoxib }\end{array}$ & \\
\hline
\end{tabular}


Table 9. Role of the crucial genes available in the intersection of merged motifs of HCoV-OC43 and SARS-COV-2 in the nervous system 


\begin{tabular}{|c|c|c|c|c|}
\hline $\begin{array}{l}\text { Gene } \\
\text { name }\end{array}$ & $\begin{array}{l}\text { NSPCs }{ }^{a} \text { proliferation } \\
\text { / differentiation }\end{array}$ & Synaptic function & others & references \\
\hline \multirow[t]{2}{*}{ IL-6 } & $\begin{array}{l}\text { Neurogenesis, } \\
\text { gliogenesis }\end{array}$ & & $\begin{array}{l}\text { neuronal myelination, } \\
\text { neurotrophin release }\end{array}$ & $\begin{array}{l}\text { Islam, Gong et al. } \\
\text { 2009, }\end{array}$ \\
\hline & & & & $\begin{array}{l}\text { Nakanishi, Niidome } \\
\text { et al. 2007, Oh, } \\
\text { McCloskey et al. } \\
2010\end{array}$ \\
\hline TNF- $a$ & & & $\begin{array}{l}\text { promote neuronal death or } \\
\text { survival, depending on the } \\
\text { types of target neurons } \\
\text { and receptor subtypes } \\
\text { (TNFRI or TNFRII) }\end{array}$ & $\begin{array}{l}\text { Leung and Cahill } \\
2010 \text {, Yang, } \\
\text { Lindholm et al. } \\
2002\end{array}$ \\
\hline HOXA5 & synaptogenesis & $\begin{array}{l}\text { synaptic } \\
\text { transmission, } \\
\text { synaptic plasticity } \\
\text { of pre-cerebellar } \\
\text { circuits }\end{array}$ & & $\begin{array}{l}\text { Lizen, Moens et al. } \\
2017\end{array}$ \\
\hline POU2F2 & $\begin{array}{l}\text { dorsal interneurons } \\
\text { (dINs) differentiation } \\
\text { and distribution }\end{array}$ & & & $\begin{array}{l}\text { Masgutova, Harris } \\
\text { et al. } 2019\end{array}$ \\
\hline ITGB3 & & $\begin{array}{l}\text { regulates both } \\
\text { structure and } \\
\text { function of } \\
\text { serotonergic and } \\
\text { glutamatergic } \\
\text { synapses in the CNS }\end{array}$ & & $\begin{array}{l}\text { Mazalouskas, } \\
\text { Jessen et al. } \\
\text { 2015, Pozo, } \\
\text { Cingolani et al. } \\
\text { 2012, Varney, } \\
\text { Polston et al. } 2015\end{array}$ \\
\hline STAT1 & $\begin{array}{l}\text { increase the } \\
\text { proliferation of } \\
\text { NSCs but decrease } \\
\text { their differentiation } \\
\text { into neurons and } \\
\text { glia cells }\end{array}$ & & & Liu, Yu et al. 2019 \\
\hline YY1 & neural development & $\begin{array}{l}\text { synaptic } \\
\text { transmission and } \\
\text { plasticity }\end{array}$ & myelination & $\begin{array}{l}\text { He and Casaccia- } \\
\text { Bonnefil 2008, Wu } \\
\text { and Donohoe } \\
2019, \text { Zolova and } \\
\text { Wight } 2011\end{array}$ \\
\hline E2F6 & $\begin{array}{l}\text { decrease the } \\
\text { proliferation of } \\
\text { NSCs but increase } \\
\text { their differentiation }\end{array}$ & & & $\begin{array}{l}\text { Pennycook, Vesela } \\
\text { et al. 2020, Wang, } \\
\text { Choi et al. } 2013\end{array}$ \\
\hline ESR1 & & $\begin{array}{l}\text { synaptic plasticity } \\
\text { and } \\
\text { neurotransmission }\end{array}$ & $\begin{array}{l}\text { improve cerebral blood } \\
\text { flow and neuronal repair }\end{array}$ & $\begin{array}{l}\text { Ma, Tang et al. } \\
2014\end{array}$ \\
\hline F0X03 & $\begin{array}{l}\text { long-term } \\
\text { maintenance of the } \\
\text { NSPC pool to protect } \\
\text { cognition function } \\
\text { during aging }\end{array}$ & & $\begin{array}{l}\text { prevents age-dependent } \\
\text { axonal degeneration }\end{array}$ & $\begin{array}{l}\text { Renault, Rafalski et } \\
\text { al. } 2009\end{array}$ \\
\hline
\end{tabular}




\section{F0X01}

control energy balance and glucose homoeostasis
Doan, Kinyua et al. 2016

synapse

development and

neural plasticity

Majidi, Reddy et al. 2019, Chen, Gao et al. 2017, Zhu, Carmichael et al. 2018

Hunt, Raivich et al. 2012 immune cell interactions

contributes with neurotrophin neuroprotection

Lange, Chavez et al. 2008, Li, Jin et al. 2018

Kennedy, Rahn et al. 2016

associated with Memory Function and language development
BCL2L2 neuronal

development

involves in neurotrophin survival responses

Hartman and Czyz 2020, Cosker, Pazyra-Murphy et al. 2013

BMP4 neurogenesis, synaptogenesis regulation of appropriate synaptic density
Liu, Amar et al. 2018, Higashi, Tanaka et al. 2018

induce neuronal apoptosis in response to neurotrophin deprivation and ischemia
Imamura, Satoh et al. 2008, Ragel, Couldwell et al. 2007

${ }^{a}$ Neural stem/progenitor cells, ${ }^{b}$ Extracellular signal-regulated kinase

\section{Figures}




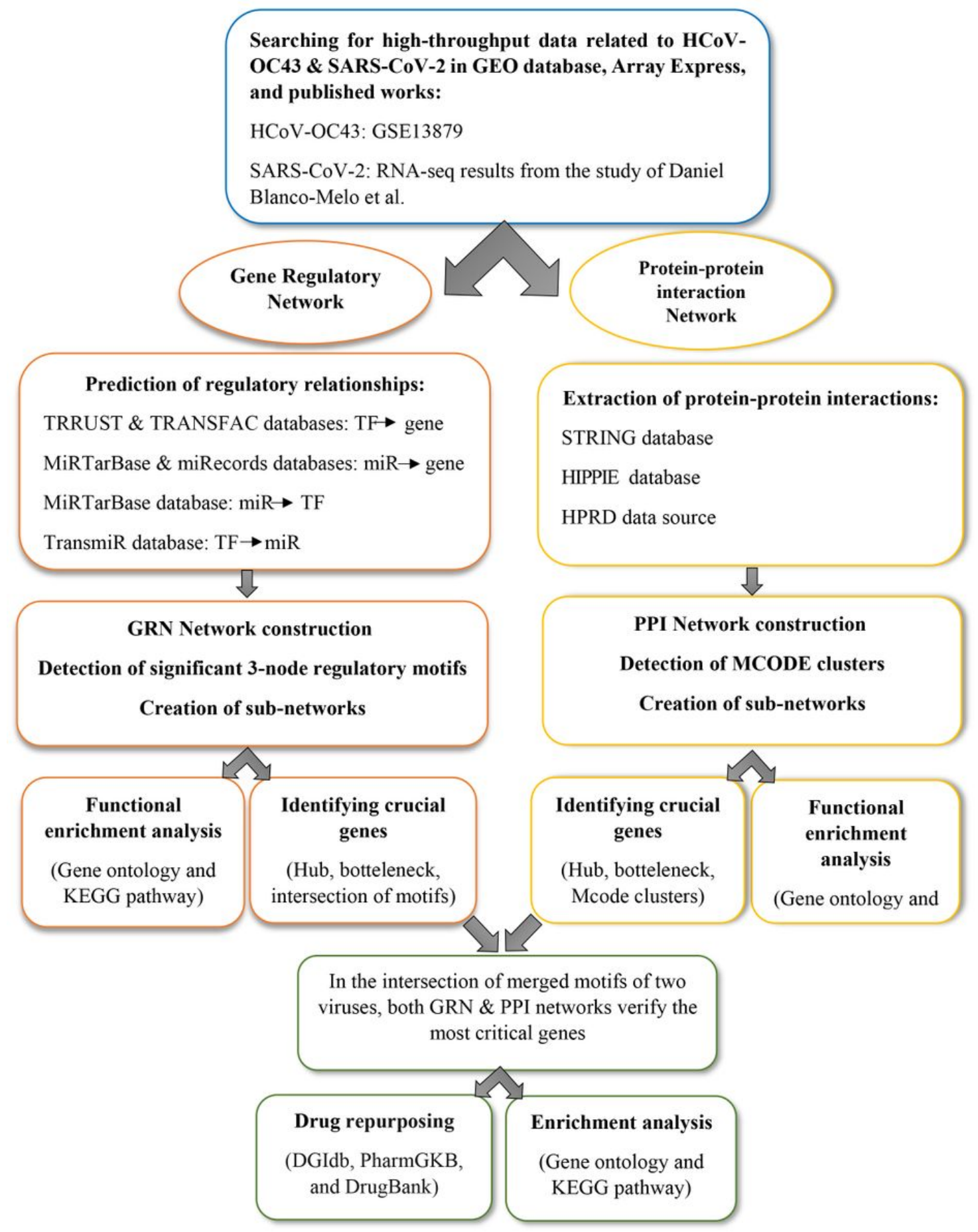

Figure 1

the workflow of the study 
a

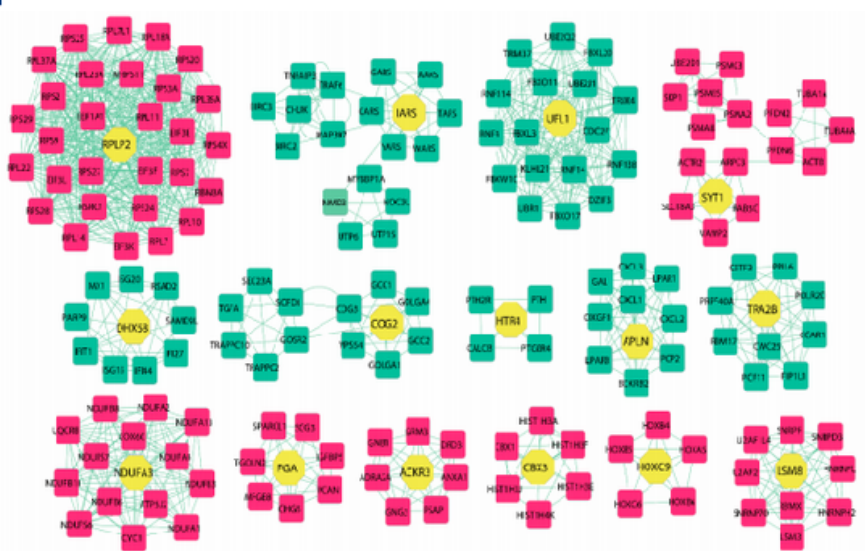

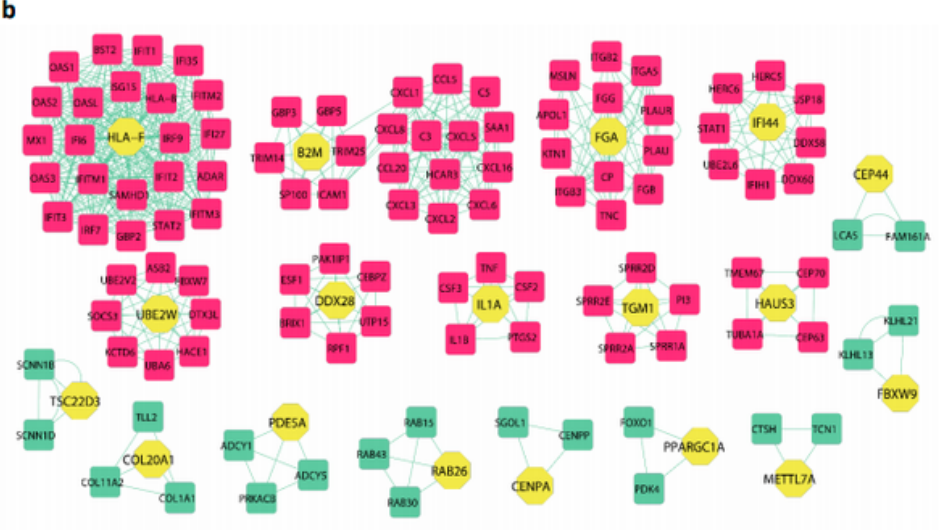

\section{Figure 2}

Merge of selected clusters of PPI network of up \& down-regulated genes of OC-43 treated cells (a) Merge of selected clusters of PPI network of up \& down-regulated genes of SARS-CoV-2 treated cells (b) Seed genes are shown in yellow octagons. Up and down-regulated genes are pink and green rectangles, respectively. 


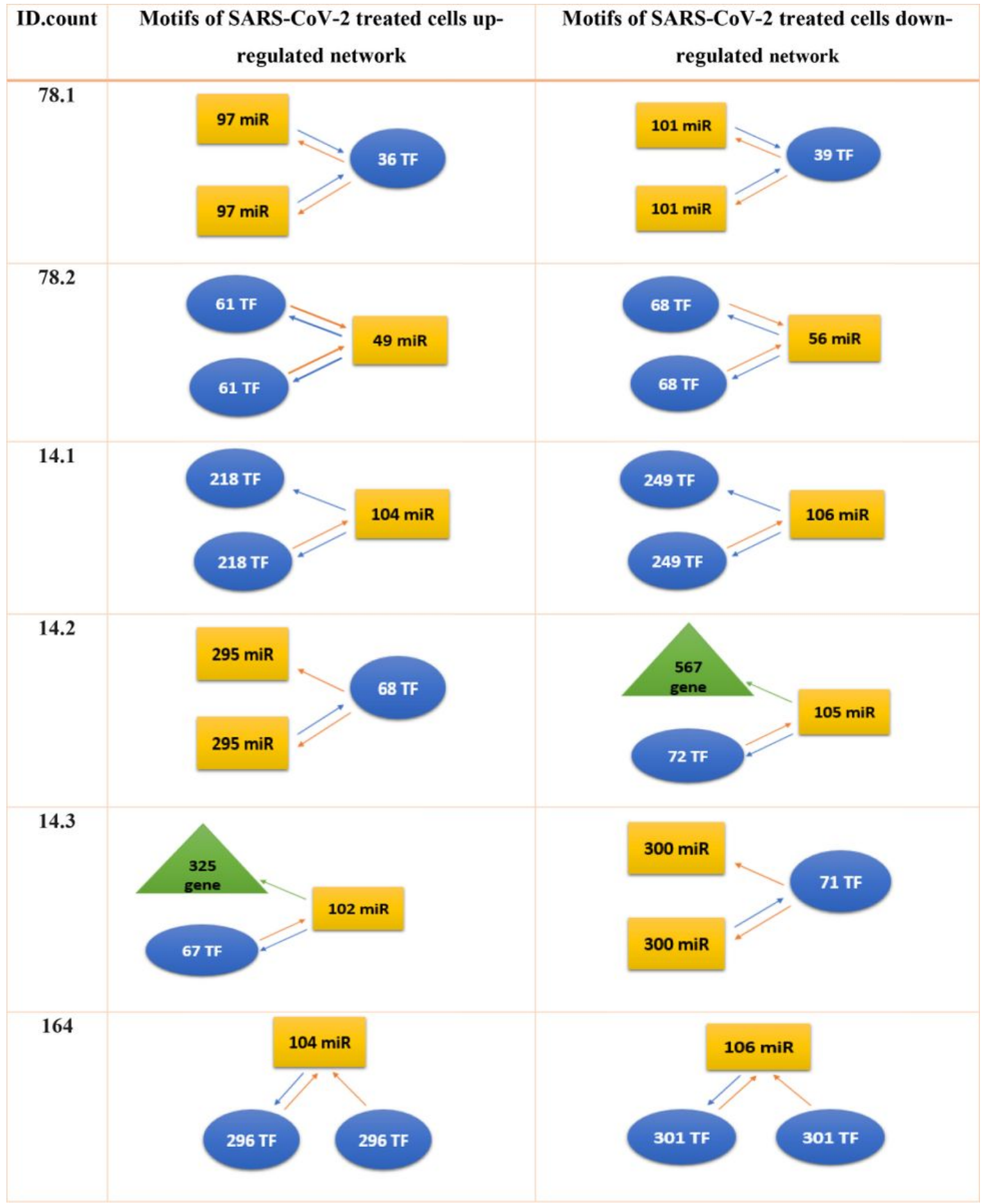

\section{Figure 3}

Selected GRN motifs of HCoV-OC43 DEGs network 


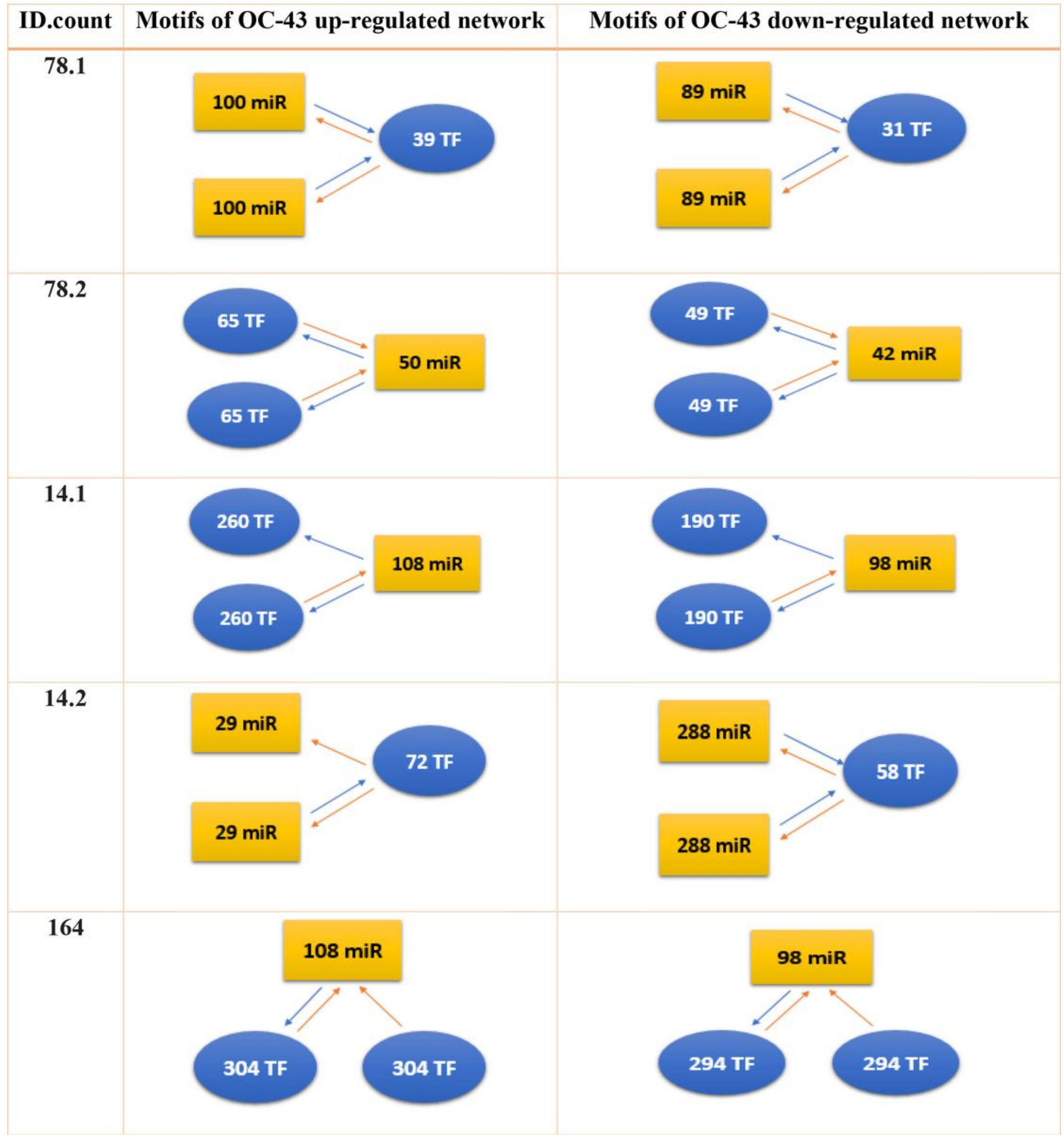

Figure 4

Selected GRN motifs of SARS-CoV-2 DEGs network 

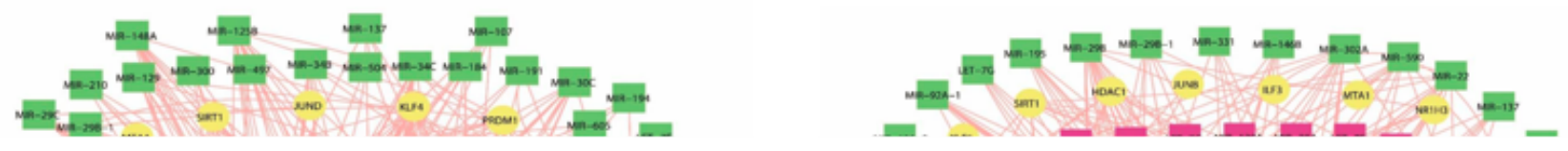

\section{Figure 5}

The intersection of merged motifs with the same FANMOD ID of up-regulated DEGs (a) and down-regulated DEGs (b) network of HCoV-OC43 treated cells The intersection of merged motifs with the same FANMOD ID for upregulated DEGs (c) and for down-regulated DEGs (d) network of SARS-CoV-2 treated cells 


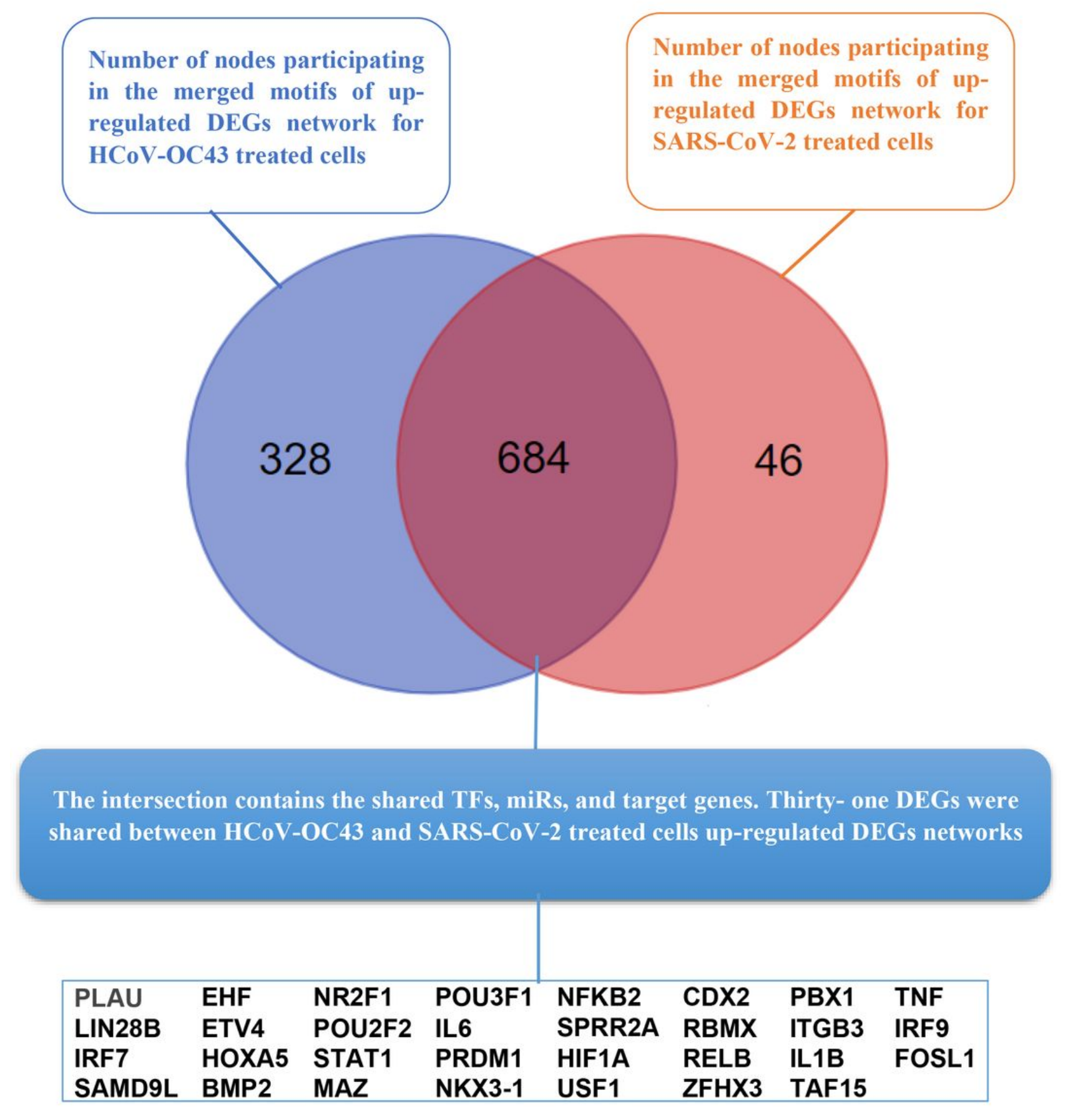

Figure 6

The intersection of the merged motifs between the HCoV-OC43 and SARS-CoV-2 treated cells up-regulated DEGs networks 


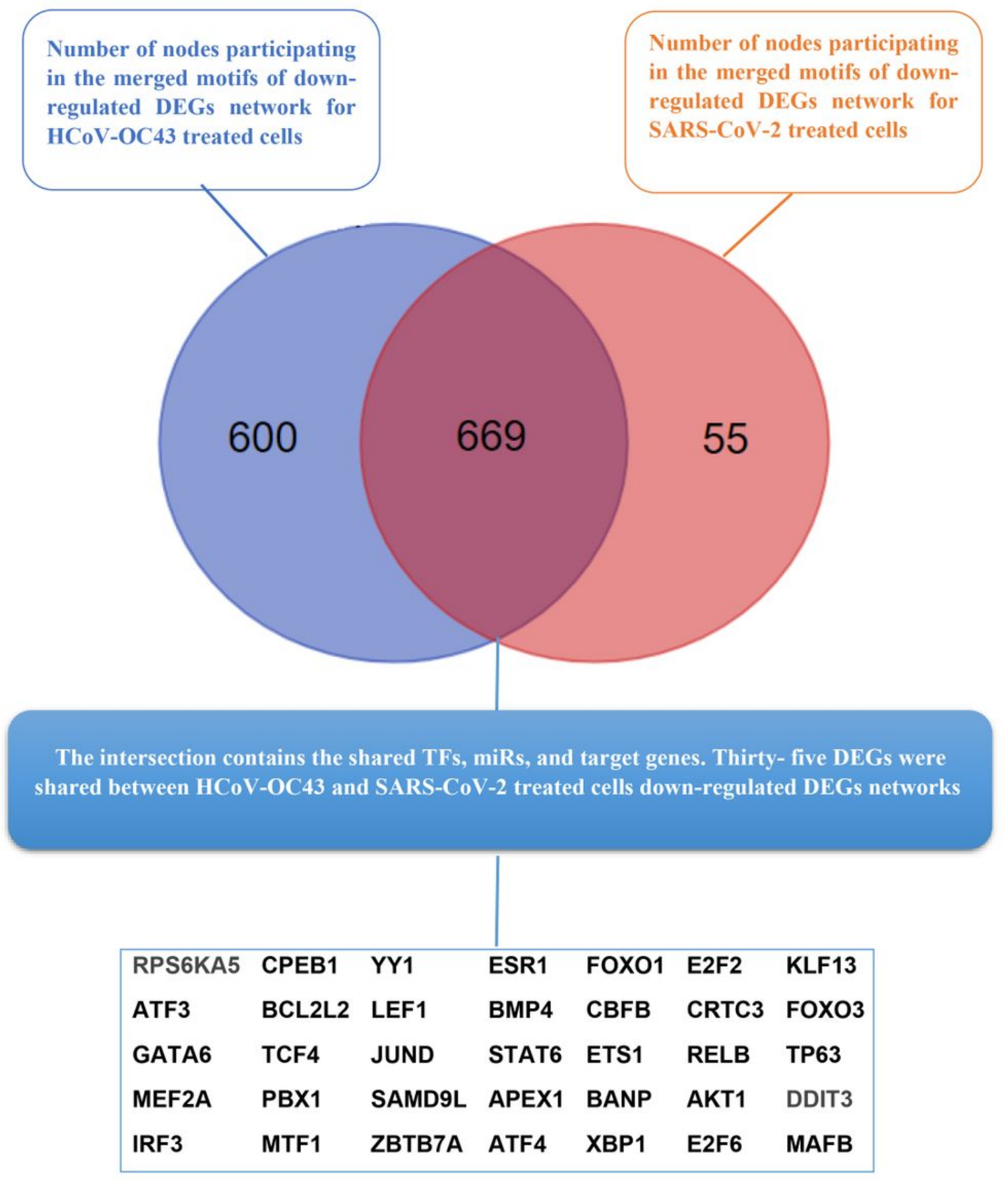

\section{Figure 7}

The intersection of the merged motifs between the HCoV-OC43 and SARS-CoV-2 treated cells down-regulated DEGs networks 


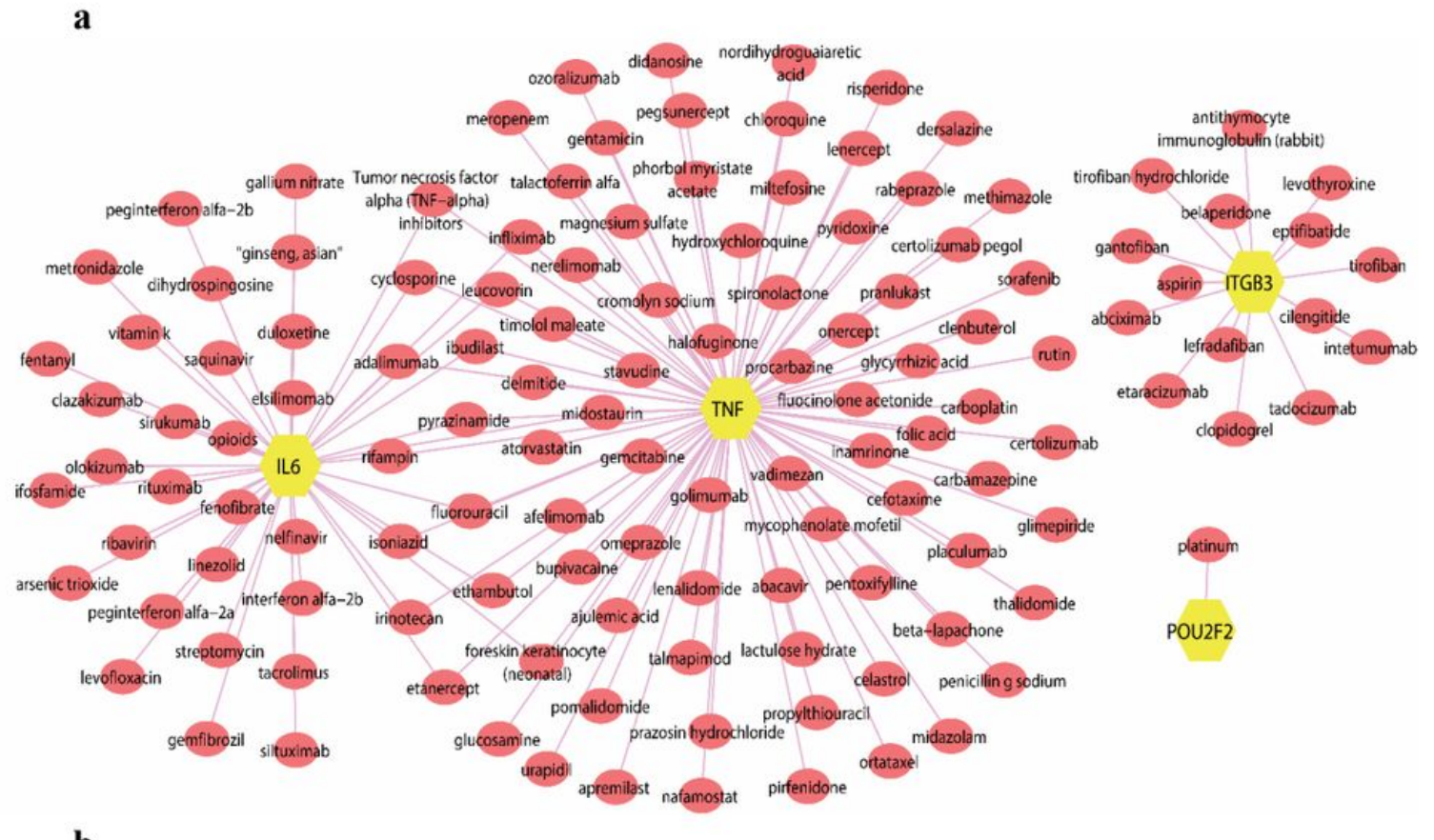

b

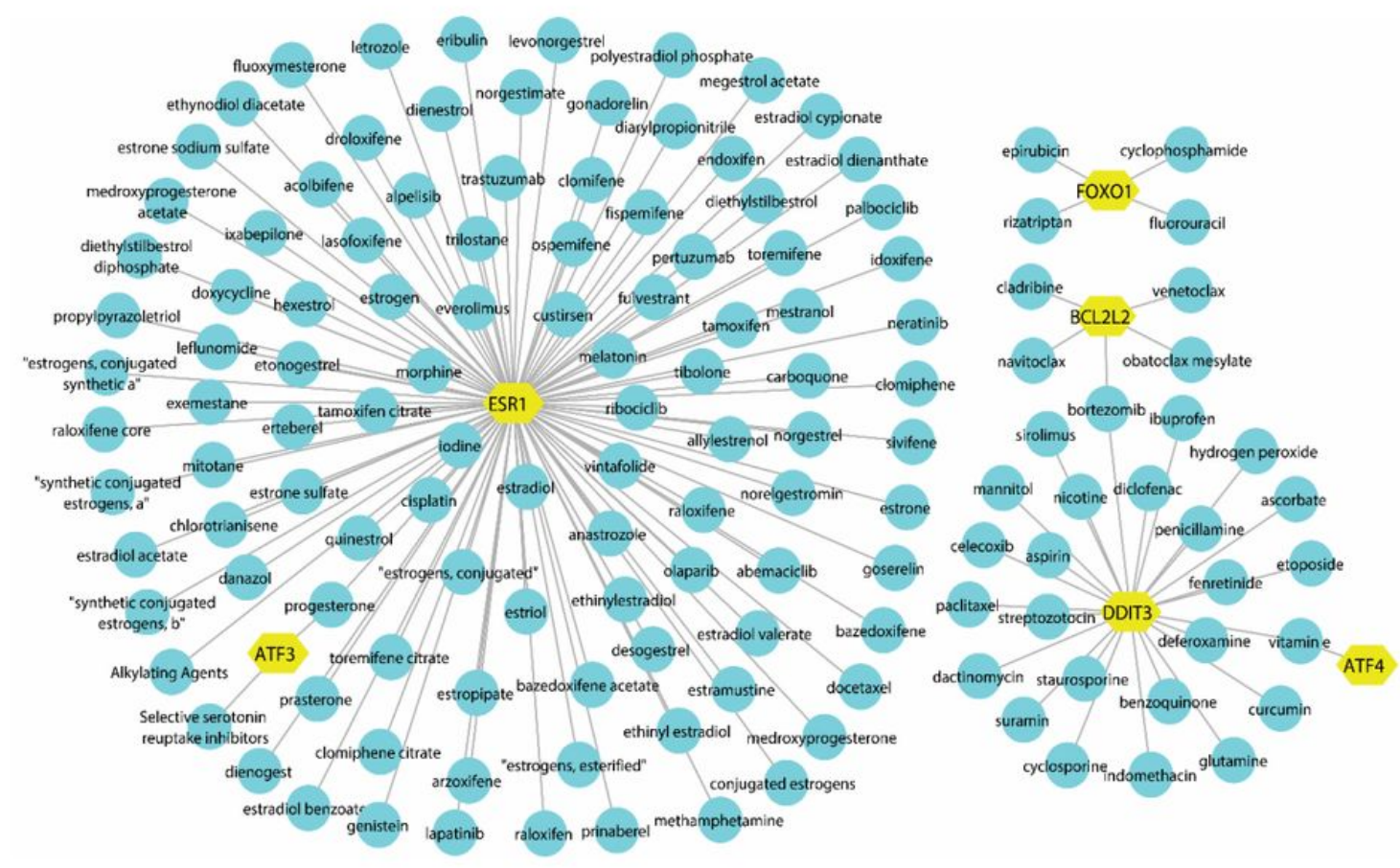

\section{Figure 8}

Drug- gene interactions of the most crucial shared up-regulated genes (a) and down-regulated genes (b) of the intersection of merged motifs in the two GRN networks, involved in neurological processes 


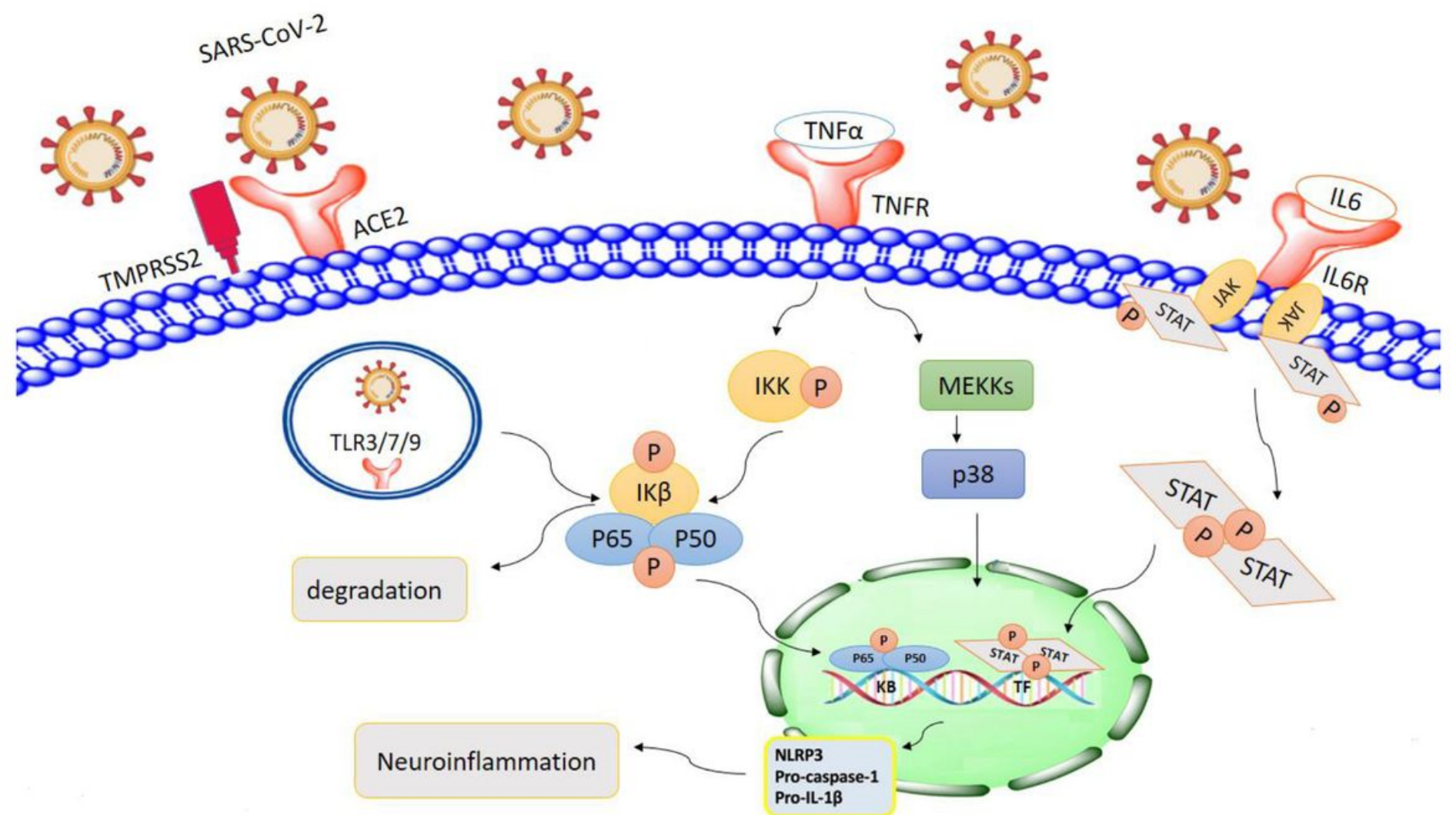

Figure 9

The picture depicts the molecular mechanisms of the identified enriched pathways (JACK-STAT, NF-K $\beta$, p38 MAPK, TLR, NLR), probably mediating in the COVID-19 pathogenesis

\section{Supplementary Files}

This is a list of supplementary files associated with this preprint. Click to download.

- GraphicalAbstract.tif

- supplementaryfigures.docx

- supplementarytables.xlsx 